\title{
A synopsis of the tribe Desmodieae (Fabaceae) in southern Africa
}

\author{
B. D. SCHRIRE*
}

Keywords: Alysicarpus, Desmodieae, Desmodium, Fabaceae, key, Lespedeza, Papilionoideae, Pseudarthria, southern Africa, synopsis

\section{ABSTRACT}

The tribe Desmodieae has a pantropical distribution and is one of the most advanced tribes in the subfamily Papilionojdeae. Its greatest centres of development are in tropical Asia and America. Africa is relatively poorly endowed and only four genera comprising 16 species occur in the flora of southern Africa. Many of these species are widespread in the Old World tropics and the few African endemics appear to be closely related to them. A synopsis of the genera Desmodium. Pseudarthria, Alysicarpus and Lespedeza is given for southern Africa.

\section{UTTTREKSEL}

Die tribus Desmodieae het 'n pantropiese verspreiding en is een van die mees gevorderde tribusse in die subfamilie Papilionoideae. Die grootste sentrums van ontwikkeling is in tropiese Asië en Amerika. Die groep is swak verteenwoordig in Afrika en slegs vier genusse wat 16 spesies insluit, kom in die flora van suidelike Afrika voor. Baie van hierdie spesies is wydverspreid in die Ou Werreldse trope en dit lyk asof die paar wat endemies in Afrika is, naverwant aan hulle is. ' $n$ Samevarting van die genusse Desmodium, Pseudarthria, Alysicarpus en Lespedeza word vir suidelike Afrika gegee.

\section{INTRODUCTION}

The tribe Desmodieae comprises 27 genera with a mainly tropical distribution and is distinguished from the other tribes with jointed indehiscent fruits by the presence of (1-) 3-foliolate leaves with stipels (Ohashi 1971a).

Three subtribes have been recognized in the latest treatment of Ohashi, Polhill \& Schubert (1981). The largest and most polymorphic of these is the subtribe Desmodiinae which is represented in southern Africa by three genera, Desmodium, Pseudarthria and Alysicarpus. The much smaller subtribe Lespedezinae is only represented in the flora by the naturalized bush-clover genus, Lespedeza. The type genus, Desmodium, is the most widespread genus in the tribe and with about 300 species (Ohashi et al. 1981) is also the most numerous. It occurs widely in the tropical and subtropical regions of America, Asia, Australia and Africa with two major centres of diversification: firstly, in Mexico and Brazil, where there is perhaps the largest number of species with the most diverse development of plant parts (Schubert 1963); and then in Asia (the Sino-Indian region down through Malesia to Australia) where there are large numbers of species in many subgeneric groups. In addition the least specialized subgenera and the most archaic genera in the tribe are found in the Asian region, indicating a possible centre of origin for the genus (Ohashi et al. 1981).

Of the ten species of Desmodium found in southern Africa most have an Asian origin, although there are a few that are endemic in Africa. Some too, are naturalized introductions from the New World. Pseudarthria with 4 to 6 species and Alysicarpus with 25 to 30 species are in the main, tropical Old World genera. These are

\footnotetext{
* Botanical Research Institute, Private Bag X101, Pretoria 0001. Presently: South African Liaison Officer, Royal Botanic Gardens, Kew, Richmond, Surrey, TW9 3AE. England.

MS. received: 1985.09.01.
}

represented in the flora of southern Africa by one and four species respectively. Southern Africa contains the tail-end of the tribe's tropical African distribution as well as a number of naturalized introductions. All specimens examined are listed alphabetically according to the name of the collector after the references at the end of the article.

The Desmodieae is a tribe of annual herbs or, more commonly, perennial suffrutices occupying, in southern Africa, the southerly extension of the large Sudano-Zambezian region of savanna and woodland areas of tropical Africa, and to a lesser extent the Afromontane and Indian Ocean coastal belt vegetation types of Werger (1978). In general the tribe occurs in the warmer and wetter parts of the Flora area.

\section{TAXONOMIC BACKGROUND}

In 1753 Hedysarum L. was published in Species plantarum along with two species occurring in the Flora area. $H$. gangeticum and $H$. vaginale. In $1759 H$. barbatum was published by Linnaeus in Systema naturae. From then until the early $1800^{\prime}$ s various authors described other species in Hedysarum: Aublet (1775), H. racemosum (=H. incanum); Swartz (1788), H. adscendens and $H$. tortuosum; Vahl (1791), $H$. repandum and $H$. glumaceum; Willdenow (1802), $H$. velutinum and $H$. rugosum and Poiret (1805), H. salicifolium.

It was recognized that several different genera existed in Hedysarum and in 1803 Michaux described the genus Lespedeza. Don transferred Anthyllus cuneata Du Mont. to this genus in 1832. In 1813 Desvaux described Desmodium and Alysicarpus and in 1825, A. P. de Candolle placed all the above-mentioned species, with the exception of $H$. barbatum, into one or other of these genera.

A. P. de Candolle also described the genus Nicolsonia into which Meyer (1836) placed two new species occurring in the Flora area, $N$. caffra and $N$. setigera. The genus Pseudarthria was published at the same time as 


\section{KEY TO SUBTRIBES}

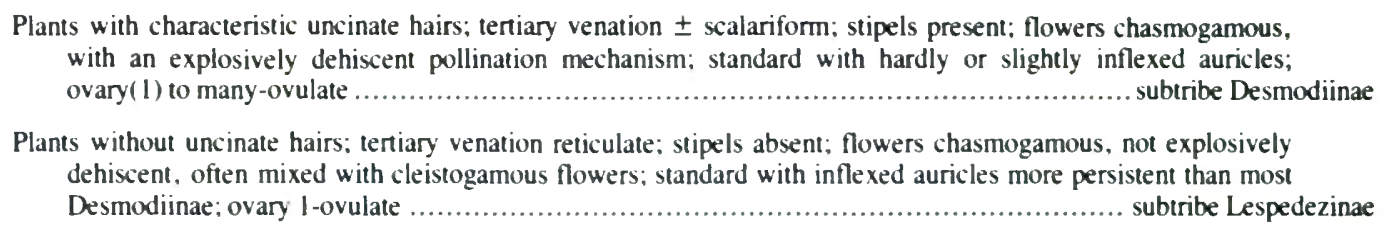

the species $P$. hookeri by Wight \& Arnott in 1834 . Bentham, in his review of the Leguminosae in 1852, placed Hedysarum barbatum and Nicolsonia caffra under Desmodium, calling the latter Desmodium dregeanum. Harvey (1862), in revising the South African representatives of the tribe for Flora capensis, placed Nicolsonia setigera under Desmodium and described a new species, Alysicarpus zeyheri. The genus Nicolsonia was later put into synonomy with Desmodium.

Other major contributors to the literature on the tribe include Baker (1871), Schindler (1928), Baker, E. G. (1929), Schubert \& Verdcourt (1971), Ohashi (1971b, 1973), Verdcourt (1974), Ohashi. Polhill \& Schubert (1981) and Schrire (1984).

The subgeneric treatment of Desmodium is as yet unsatisfactory but for the purposes of this synopsis the treatment of Ohashi (1973) is followed, i.e. D. repandum is placed in subgenus Podocarpium; $D$. setigerum, $D$. adscendens, $D$. barbatum and $D$. dregeanum in subgenus Nicolsonia and the rest in subgenus Heteroloma.

\section{TRIBE DESMODIEAE}

Desmodieae (Benth.) Hutch., The genera of flowering plants 1: 477 (1964), pro parte; Schubert \& Verdc.: 450 (1971); Verdc.: 505 (1974); Ohashi et al.,: 292 (1981). Type genus: Desmodium Desv.

Coronilleae Adans.: 327 (1763), pro parte.

Hedysareae DC : 307 (1825), pro parte.

Hedysareae subtribe Desmodiinae (as Desmodieae) Benth.: 449 (1865), pro parte; Taub.: 325 (1894), pro parte.

Coronilleae subtribe Desmodiinae (Benth.) SchulzMenz: 237 (1964), pro parte; Ohashi: 52 (1971a).

Herbs or suffrutices, sometimes shrubs or rarely trees. Roots woody, often dichotomously branched, cord-like and producing rhizomes, or more rarely taproots. Leaves pinnately 3-(9)- or 1-foliolate, petioles sulcate, foliar and foliolar pulvini present, stipellate (except Le'spe- deza); stipules mostly striate. Pseudoracemes variously contracted, terminal, axillary or occasionally leafopposed, sometimes paniculately branched. Flowers pedicellate, fasciculate, mostly paired, rarely solitary on the rhachis, usually subtended by 2 series of bracts and occasionally bracteoles. Calyx 2-lobed, the upper with 2 connate sepals often slightly bifid at the apex, the lower 3-toothed with the central tooth longer than the laterals, or the calyx almost equally 5-lobed. Corolla papilionoid. Stamens mostly diadelphous with the vexillary stamen free, rarely pseudo-monadelphous; filaments equal or alternating in length; anthers uniform. Pollen tricolporate with a generally thickened endexine and thin or no foot layer. Fruits transversely jointed into a number of articles or reduced to one article, or less often 2-valved, opening along one suture (valves not twisting). Seeds with a well developed radicular lobe, longer than the cotyledonary lobe, mostly with a rim aril. Seedlings generally epigeous with the first two eophylls opposite and unifoliolate.

\section{Subtribe Desmodiinae}

Desmodiinae sensu Ohashi et al. in Advances in legume systematics 1: 296 (1981).

Pseudarthrieae Hutch.: 398 (1964), pro parte.

\section{DESMODIUM}

Desmodium Desv., Journal de botanique 1: 122 , t.5 (1813) nom. conserv.; DC.: 325 (1825); Benth.: 220 (1852); Harv.: 227 (1862); Benth.: 519 (1865); Harv.: 82 (1868); Bak.: 159 (1871); Bak.: 161 (1876); Taub.: 327 (1894); Schindl.: 263 (1928); Hutch. \& Dalz.: 417 (1928); Bak.f.: 324 (1929); Phill.: 332 (1951); Schubert: 287 (1952); Schubert: 180 (1954); Hepper: 582 (1958); Knaap-van Meeuwen: 240 (1962); Hutch.: 481 (1964); Torre: 217 (1966); Schreiber: 30 (1970); Schubert: 451 (1971); Ohashi: 87 (1973); Verdc.: 506 (1974); Dyer: 263 (1975); Compton: 272 (1976); Schubert: 622 (1980). Type species: D. scorpiurus (Swartz) Desv. (Hedysarum scorpiurus $\mathrm{Swartz}$ ).

\section{KEY TO GENERA}

la Calyx often membranous, never glumaceous or striate, shallowly divided, usually inconspicuous in fruit: fruit mostly held away from erect; leaves (1) - 3- (5)-foliolate:

2a Stipules stramineous, striate, erect or spreading but never sharply recurved and velutinous: fruit distinctly

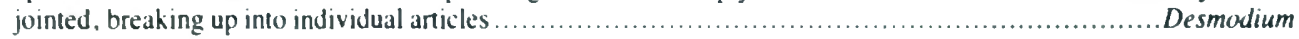

2b Stipules mostly sharply recurved, dark brown adaxially, silver-velutinous abaxially; fruit splitting into 2

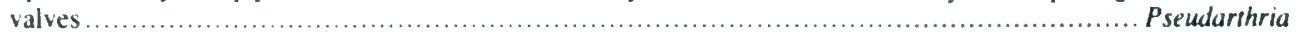

Ib Calyx glumaceous, striate, deeply divided, persistent and often partially enclosing the fruit; fruit held erect, usually consisting of a number of "stacked" terete or subterete articles; leaves 1 -foliolate...................... Alysicarpus 
Hedysarum L.: 745 (1753), pro parte (name still correct for other plants).

Meibomia Heist. ex Fabricius: 168 (1759), nom. rejic.; Adans.: 509 (1763); Kuntze: 195 (1891).

Nicolsonia DC.: 325 (1825).

The name Desmodium was conserved over the name Meibomia by the International Botanical Congress of Vienna in 1905 (Schubert 1950). Desmodium is derived from the Greek 'desmos' meaning a band or chain, and 'hode' meaning like, in reference to the jointed pod's resemblance to the links of a chain.

\section{SYNOPSIS OF SPECIES}

1. Desmodium repandum (Vahl) $D C$., Prodromus systematis naturalis regni vegetabilis 2: 334 (1825);
Schindl.: 295 (1928); Schubert: 293 (1952); Schubert: 193, t.14 (1954); Hepper: 584 (1958); White: 150 (1962); Laundon: 221 (1966); Schubert: 465, t. 65/11 (1971); Verdc.: 517 (1974); Compton: 272 (1976). Type: Yemen, Forsskål (C, holo., fide Schindl.-GH, photo.!).

\section{Hedysarum repandum Vahl: 32 (1791); Poir.: 408 (1805).}

Desmodium scalpe DC.: 334 (1825); Bak.: 164 (1871); Hutch. \& Dalz.: 418 (1928): Bak. f.: 328 (1929); Robyns: 327, t.30 (1948): Brenan: 420 (1949). Type: Mauritius (Isle de Bourton), Commerson (P-LA, holo.; GH, photo.!)

Desmodium strangulatum Wight \& Am.: 228 (1834); Harv : 228 (1862). Type: E Peninsular India, Walker in Wight cat. no. 774 (K. holo.!; $\mathrm{GH}$ )

Desmodium caffrum Eckl. \& Zeyh.: 251 (1836) non (E.Mey.) Druce: 619 (1917), which is a later illegitimate name for $D$. dregeanum Benth. Type: E Cape, Mankazana R., Eckl. \& Zevh. in Enum. 1662 ( $\mathrm{K}$, iso.!).

\section{KEY TO SPECIES}

la Inflorescences of variously lax to dense, elongated, axillary and terminal pseudoracemes, the terminal ones often paniculately branched; calyx teeth shor, triangular or lanceolate, the adaxial two usually markedly connate forming a lip:

2a Flowers 8,0-14,0 mm long, brick red; herbs or subshrubs, climbing or scrambling and forming a dense undergrowth in forest; leaflets rhomboid, deep green venation craspedodromous; inflorescences very lax;

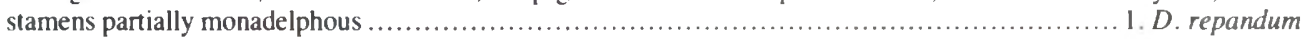

2b Flowers 4,5-8,0 mm long, variously pink, mauve or purple but never red; plants not as above, stamens always diadelphous:

3a Plants becoming erect to semi-erect suffrutices or subshrubs if not burned: leaflets never obovate, lateral veins not obviously looping in the distal half of the leaves; floral bracts present; inflorescences variously contracted:

4a Flowers uniformly deep mauve; pseudoracemes terminal only, and never paniculately branched; leaflets glossy dark green with characteristic light discolouration along the midrib above; widespread weeds of disturbed areas in coastal Zululand, Natal, Transkei and eastern Cape to $1000 \mathrm{~m} \ldots \ldots \ldots \ldots \ldots$...... D. incanum

4b Flowers light pink or purple, dark purple only at the tip of the keel; pseudoracemes terminal and often axillary, the terminal ones often paniculately branched; leaflets various, not as above:

5a Leaves trifoliolate:

6a Venation mixed craspedodromous with principal lateral veins prominent and parallel; leaflets distinctly saliciform; stipules not as below; articles of the fruit rectangular or oblong, not or slightly constricted at the isthmi; shrub growing in or near water 4. D. salicifolium

6b Venation eucamptodromous, lateral veins neither prominent nor regular; stipules markedly auriculate at the base on the leaf-opposed margin, fused into a collar around the stem when young; articles of the fruit orbicular to elliptic, strongly constricted at the isthmi; introduced weed with a restricted distribution...

5b Leaves unifoliolate:

7a Leaflets chartaceous, ovate or cordiform with entire margins, venation eucamptodromous; stipules gradually narrowing from the base to a slender apex....

6. D. gangeticum

7b Leaflets crassate, velutinous, suborbicular, often with sinuate margins; venation craspedodromous; stipules abruptly narrowing from an auriculate base to a long slender apex............... 5. D. velutinum

3b Plants procumbent, or stoloniferous creepers; leaflets obovate. Iateral veins obviously looping in the distal half of the leaves; floral bracts usually absent; inflorescences lax:

8 a Procumbent herbs rooting from the lower nodes, in open grassland to forest fringes, often drying brown or grey-green in herbarium specimens; articles of the fruit U-shaped, 1,5-2,0 $\mathrm{mm}$ wide

$8 \mathrm{~b}$ Stoloniferous herbs of moist forest and forest margin undergrowth, often drying deep green in herbarium specimens; articles approximately obtriangular, 2,5-3,0 $\mathrm{mm}$ wide

8. D. adscendens

lb Inflorescences congested into dense spicate or capitate pseudoracemes, never paniculately branched but often with the upper axillary and terminal inflorescences crowded together; calyx teeth long-acuminate, the adaxial two not markedly connate:

9a Leaves variously 3 or 1-foliolate; inflorescences spicate; pedicels often dark-coloured, visibly deflexed distally; bracteoles absent; woody herbs in mixed open woodland; northem and eastem

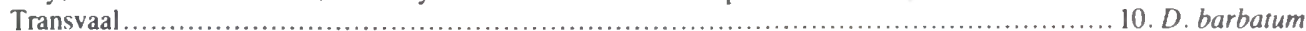

9b Leaves 3-foliolate, conduplicate; inflorescences densely capitate; pedicels not obvious; bracteoles 2 ,

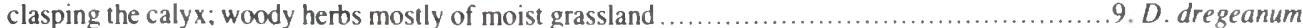


Distribution: 1, Transvaal-a, in Mixed and Sourish Mixed Bushveld, Acocks Veld Types 18 \& 19, from Zeerust in the west to near Witbank in the east; $b$, in similar bushveld or in other types of Sourveld and Sour Bushveld, Acocks Veld Types $8 \& 9$, from Louis Trichardt. Pietersburg and Tzaneen in the north, between Lydenburg and Graskop, Belfast and Barberton, to western Swaziland in the south. It does not occur in the Lowveld. 2, Natal-where suitable forest patches occur from the Drakensberg to almost sea level except in coastal Dune forest. 3, Transkei and eastern Cape to the coastal southern Cape at Knysna.

This species is widespread in tropical and subtropical Africa, Madagascar, the Mascarene Islands, India and south-east Asia to Malesia.

Vouchers: Compton 27287 (PRE, SAM); Flanagan 515 (BOL. GRA. NBG. NU. PRE, SAM); B. \& C. Howlett 16 (NH, NU, PRE); Kluge 467 (PRE. PRU); Wells 2880 (GRA. NH. PRE).

Notes

(1) Desmodium repandum is found in shaded areas in moist to dry evergreen mountain, riverine or other gallery forest often near paths or along streams, from \pm $3000 \mathrm{~m}$ to near sea level. It occurs as a forest floor herb or scrambling subshrub. Flowering is from August to June although most commonly from January to May.

(2) In the latest Asian revision of Desmodium by Ohashi (1973). D. repandum is placed in the most advanced subgenus Podocarpium, because it is characterized by a monadelphous androecium and long-stipitate pods consisting of indehiscent, approximately obtriangular articles. However, the androecium cannot be considered to be truly monadelphous, the vexillary stamen being coherent (not fused) for part of its length only. The pollen grains are also quite distinct from those of all other species of the subgenus Podocarpium, especially in the shape of the grains, the colpi and thickness of the exine (Ohashi 1973). D. repandum is also noted (Ohashi 1973) for having several characters in common with some members of the less derived subgenus Dollinera.

From observations on the degree of contraction of the pseudoraceme in $D$. repandum it appears that this also shows a less derived situation. Occasionally one pedicel may be seen to branch off another, above the fascicle, indicating incomplete reduction of the botrys. A number of pedicels also occur in the fascicle, three or four of which may flower with one or two reduced buds in between. The fascicle in all the other species in the Flora area has been reduced to two pedicels with or without one enclosed median bud.

2. Desmodium incanum $D C$., Prodromus systematis naturalis regni vegetabilis 2: 332 (1825); Bak.: 163 (1871); Hutch. \& Dalz.: 418 (1928); Nicolson: 365 (1978). Type illustration: Plumier, in J. Burman. Pl. Amer.: 140. t. 149, fig. 1 (1757)-Hedysarum folii's ternatis, ovatis, floribus spicatis (!).

Hedisarum racemosum Aubl:: 774 (1775). Type: as for species This is the first legitimate name but the epithet is unavailable in Desmodium. Hedvsarum incanum Swartz: 107 (1788) reprint 1962; Swartz 1264 (1806), non Thunb (1784). Illegitimate renisusing of $H$. racemosum Aubl. Hedssarum canum J. F. Gmel: 1124 (1791), non Lunan (1814). Superfluous renaming of $H$. racemosum Aubl. Desmodium canum (J. F. Gmel.) Schinz \& Thell.: 371 (1913); Schinz \& Thell.: 428 (1913): Schuben: 184 (1954): Hepper: 584 (1958); Schuben: 456
(1971). Treated as a new name with priority from publication because of the illegitimate basionym, it is a superfluous renaming of $D$. incanum DC

Hedysarum frutescens auct. non L.: Jacq.: 47, t. 89 (1776)

Desmodium frutescens sensu Schindl.: 9 (1928); Bak. f.: 328 (1929). Intended as a new combination of $H$. frustescens sensu Jacq.

Distribution: Desmodium incanum occurs along the coast and hinterland up to $1000 \mathrm{~m}$ in Natal, and in coastal Transkei just into the eastern Cape.

Vouchers: Fisher 590 (NH, NU); Gillett 1203 (BOL. NH); Grobbelaar 284 (PRE, PRU); Ward 584 (NU, PRE); Wood 644 (BOL, SAM).

Notes

(1) D. incanum is a spreading herb to woody subshrub up to $1 \mathrm{~m}$ (if protected from fire); the leaf shape may vary; leaves in deep shade may superficially resemble those of $D$. adscendens. Confusion between the two may occur on forest margins but the partially connate stipules, deep mauve flowers and characteristic fruit of $D$. incanum will help to distinguish them. $D$. incanum is otherwise readily recognized by its shiny dark green leaves with a light discolouration along the midrib. Flowering occurs from September to June.

(2) The plant is a weed in disturbed grassland, woodland and forest edges, along streams, paths and roadsides and often occurs in lawns. It is also invasive in undisturbed grassland.

(3) D. incanum is tropical American in origin but is widely scattered throughout tropical Africa where it is introduced. It is most likely to have entered the Flora area along the Natal coast. The Zulu name 'isinama' describes the fruit which readily catches and sticks to clothing. Allen \& Allen (1981) refer to the plant as Kaimi clover or creeping beggarweed and it is favoured as a forage legume in Hawaii and Florida for its tolerance to acid soils and wet warm climate.

3. Desmodium tortuosum (Swartz) DC., Prodromus systematis naturalis regni vegetabilis 2: 332 (1825); Schubert: 202 (1954); Hepper: 585 (1958); Lind \& Tallantire: 82, t. 32 (1962); Laundon: 223 (1966); Schubert: 474 (1971); Verdc.: 526 (1974). Type: Jamaica, Swartz (S, lecto. $-\mathrm{GH}$, photo.!).

Hedysarum tortuosum Swartz: 107 (1788) reprint 1962; Swartz: 1271 (1806).

Desmodium spirale auct. non (Swartz) DC.: Bak.: 160 (1871); Bak. f.: 331 (1929)

Distribution: $D$. tortuosum is an escape from cultivation which has now become naturalized in disturbed grassy areas or along roadsides, in Nelspruit in the Transvaal, and in the Durban and Port Shepstone Districts of Natal.

Vouchers: Coleman 1103 (NH): Mogg, Govt. Herb. I007I (PRE); Nichols 433 (NH); Rabie 273 (PRE).

\section{Notes}

(1) The Swartz specimen has been chosen as the type (Schubert pers. comm. 1983) in preference to the Sloan illustration: 116, t. 9 (1696), following the precept in the Guide for the Determination of Types, ICBN (Stafleu 1983), T. 4b: 'A specimen is to be given preference over pre-Linnaean or other cited descriptions or illustrations when lectotypes of names of species or infra-specific taxa are designated (see Art. 9.3)'. 
(2) D. tortuosum is an herbaceous suffrutex or small shrub to $1 \mathrm{~m}$, flowering from December to May. It is known as Florida beggarweed in the south eastern United States (Schubert 1971) and is cultivated as a green manure. It is now naturalized throughout the Old World tropics coming originally from tropical and subtropical America. The populations in Durban and Port Shepstone are large and well established.

4. Desmodium salicifolium (Poir.) DC., Prodromus systematis naturalis regni vegetabilis 2: 337 (1825). Type: Herb. de l'Inde de M. Poivre (P-Ju 15552, holo. $-\mathrm{GH}$, photo.!).

Hedisarum salicifolium Poir.: 422 (1805).

Desmodium paleaceum Guill. \& Perr.: 209 (1832). Type: Senegal, Perrottet 246 (P. holo.: W).

Desmodium grande E. Mey.: 124 (1836). Type: Durban (Port Natal), Drège (B, holo.; W, K!).

\section{var. salicifolium}

Schubert in Bulletin du Jardin botanique de l'Etat, à Bruxelles 22: 294 (1952); Schubert: 470, t. 65/1 (1971); Verdc.: 523 (1974).

Hedysarum salicifolium Poir.: 422 (1805). Desmodium salicifolium (Poir.) DC.: 337 (1825): Bak.f.: 330 (1929); Schubert: 294 (1952); Schubert: 198. t. XV (1954): Hepper: 584 (1958); White: 150 (1962); Laundon: 224. t. 20A (1966); Schubert: 469, t. 65/I (1971); Verdc.: 522 (1974).

Desmodium paleaceum Guill. \& Perr.: 209 (1832); Bak.: 166 (1871); Hutch. \& Dalz.: 418 (1928).

Desmodium grande E. Mey.: 124 (1836); Harv.: 228 (1862).

Distribution: $D$. salicifolium var. salicifolium occurs in northern South West Africa/Nambia, Caprivi and northern Botswana, and in Mozambique coming into Komatipoort and Nelspruit in the Transvaal, eastern Swaziland and southward along coastal Zululand and Natal, from 0-1000 m. It occurs widely in tropical Africa, Madagascar and the Mascarene Islands.

Vouchers: Buitendag 1155 (NBG, PRE): Moll \& Nel 5610 (NH, PRE); Venter 5489 (PRE. ZULU); Ward 5560 (NH. NU): Wylie sub Wood 10335 (GRA. PRE, SAM, STE).

\section{Note}

D. salicifolium is a suffrutex or shrub of wet places, principally along river margins or in swamp forest. It often occurs in wet clayey soil and flowers from August to May.

5. Desmodium velutinum (Willd.) $D C$., Prodromus systematis naturalis regni vegetabilis 2: 328 (1825); Schubert: 294 (1952); Schubert: 194 (1954); Hepper: 584 (1958); White: 150 (1962); Schubert: 292 (1963); Laundon: 219 (1966); Schubert: 466 , t. $65 / 7$ (1971); Verdc.: 518 (1974). Type: Herb. Willdenow 13763 (B, holo. $-\mathrm{GH}$, photo.!).

Hedysarum velutinum Willd.: 1174 (1802).

Hedisarum lasiocarpum Beauv.: 32, t. 18 (1805). Desmodium lasiocarpum (Beauv) DC.: 328 (1825): Bak.: 162 (1871): Hutch. \& Dalz.: 418 (1928): Bak.f.: 326 (1929). Type: Nigeria. Palisot de Beauvois $(\mathrm{G}$, holo. $-\mathrm{A}$, photo.!).

Distribution: $D$. velutinum is only known from the north-eastern Lowveld of the Transvaal, up to $750 \mathrm{~m}$, from near Leydsdorp to the southern boundary of the
Kruger National Park. It is widespread throughout the Old World tropics from Africa and Madagascar to India, south-east Asia and Malesia.

Vouchers: Junod sub TRV 5279 (PRE); Schrire 655 (NH): Van der Schiiff 2659 (PRE).

Note

The plant occurs as a small shrub or suffrutex in wooded and open grassland, woodland and on forest margins.

6. Desmodium gangeticum (L.) $D C$., Prodromus systematis naturalis regni vegetabilis 2: 327 (1825); Wight \& Am.: 225-226 (1834); Bak.: 161 (1871); Hutch. \& Dalz.: 418 (1928); Bak.f.: 327 (1929): Brenan: 420 (1949); Schubert: 196 (1954); Hepper: 584 (1958); White: 150 (1962); Laundon: 219 (1966); Schubert: 465 , t. 65/10 (1971); Verdc.: 520 (1974). Type: Herb. Linnaeus 921.13 (LINN, holo.-A. photo.!).

Hedysarum gangeticum L.: 746 (1753).

Hedysarum maculatum L.: 746 (1753). Desmodium gangeticum (L.) DC. var. maculatum (L.) Bak.: 168 (1876); Hepper: 584 (1958): Laundon: 220 (1966). Type: Herb. Linnaeus 921.14 (LINN, holo.-A, photo.!).

Desmodium natalitium Sond.: 32 (1850); Harv.: 229 (1862); Schindl.: 285 (1928). Type: South Africa. Port Natal. Gueinzius 203 (Herb. Sond.).

Distribution: $D$. gangeticum occurs in the Transvaal from the Soutpansberg in the north, through the Lowveld between Barberton and Nelspruit to Swaziland in the south. In Natal this distribution continues through northern Natal to Zululand and then along the coast southwards to the Transkei, from $0-1200 \mathrm{~m}$.

Vouchers: McDonald $1 / 8$ (NU. PRE); Schlechter $3 / 29$ (BOL. GRA. PRE); Van der Schiiff 965 (PRE, PUC); Ward 2406 (NH, PRE); Wood 4936 (BOL. PRE, SAM).

\section{Notes}

(1) The epithets gangeticum and maculatum were published on the same date and they were combined under the name Desmodium gangeticum by Wight \& Arn.: 225-226 (1834).

(2) The plant is a spreading suffrutex to erect subshrub occurring in wooded grassland. bushveld or thicket or in open grassland. It readily becomes a weed in semi-disturbed areas i.e. old lands or roadsides, and flowers from August to March.

(3) This species is widespread throughout the Old World tropics and has been introduced into America. Allen \& Allen (1981) note that $D$. gangeticum is used as a pioneer plant to control erosion of denuded areas. The roots of $D$. gangeticum yield a lectone and seven alkaloids. One of these, hordenine, has been used in experimental medicine as a sympathomimetic and another, bufotenine, is an hallucinogen.

7. Desmodium setigerum (E. Mey.) Benth. ex Harr. in Flora capensis 2: 229 (1862); Milne-Redh.: 417 (1937); Schubert: 187, t. IIE (1954); Hepper: 585 (1958); Laundon: 222 (1966); Schubert: 460 , t. $65 / 5$ (1971); Verdc.: 513 (1974). Type: Transkei, Umzimvubu River, Drège 446 (B, holo.; W, K!).

Nicolsonia setigera E. Mey.: 124 (1836). 
Desmodium hirtum auct. non Guill. \& Pern.: Bak.: 163 (1871), pro parte; Wood: 14, t. 212 (1902); Hutch. \& Dalz.: 418 (1928); Schindl.: 279 (1928): Bak.f.: 329 (1929), pro parte; Compton: 272 (1976).

Distribution: $D$. setigerum occurs in the Transvaal from the Soutpansberg and Tzaneen in the north, through the area between Lydenburg and Sabie to western Swaziland in the south. In Natal it is found from sea level to $2000 \mathrm{~m}$, except in the lowveld of Zululand, and it extends to coastal Transkei. It is widespread throughout tropical Africa.

Vouchers: Bos 1253 (PRE, STE); Compton 30608 (NBG, PRE); Ross 1679 (NH, NU, PRE); Scheepers 581 (PRE, PRU); Strey 2996 (NH, PRE).

\section{Notes}

(1) Misinterpretation of types (Schubert 1971) has led to confusion between two separate species, Desmodium setigerum (E. Mey.) Benth. ex Harv. and D. hirtum Guill. \& Perr. This began with $D$. hirtum sensu Bak.: 163 (1871).

(2) The plant is a prostrate or low semi-erect suffrutex of open grassland in damp sites, occurring occasionally on streambanks, forest margins or on drier rocky hillsides. It is also found in semi-disturbed vegetation on roadsides and flowers from December to May, i.e. it is a later summer-flowering species.

8. Desmodium adscendens (Swartz) DC., Prodromus systematis naturalis regni vegetabilis 2: 332 (1825); Bak.: 162 (1871); Hutch. \& Dalz.: 418 (1928); Bak.f.: 330 (1929); Brenan: 419 (1949); Laundon: 222, t. 20Al (1966). Type: West Indies, Swartz (S, holo.-GH, photo.!).

Hedysarum adscendens Swartz: 106 (1788) reprint 1962; Swartz: 1263 (1806).

var. robustum Schubert in Bulletin du Jardin botanique de l'Etat, à Bruxelles 22: 290 (1952); Schubert: 190 (1954); Hepper: 585 (1958); Schubert: 461, t. 65/13 (1971); Verdc.: 514 (1974). Type: Congo, Kivu, Mokoto Lakes, Ghesquiere 4994 (BR, holo.).

Distribution: $D$. adscendens var. robustum is found in the Soutpansberg and Woodbush areas of the northern Transvaal and entering from Mozambique along the Natal coast to the Transkei border. It is widespread in tropical Africa but the species is pantropical, from America, Africa, Asia and Malesia.

Vouchers: Gillelt 3156 (BOL, PRE, STE); Moll 2720 (NU, PRE); Moll \& Strey 3896 (NH, PRE); Strey 7151 (NH, NU, PRE); Venter 529l (PRE, ZULU).

\section{Note}

The plant is a straggling herb or undershrub of shaded mesic forest floors, and flowers from November to March. On forest margins along the coast, this species may be confused with the shade form of $D$. incanum (see under that species). Schubert (1971) records that $D$. adscendens is an excellent food for stock.

9. Desmodium dregeanum Benth. in Plantae Junghuhnianae 2: 222 in adnot. (1852); Harv.: 228 (1862); Bak.: 165 (1871); Schubert: 476, 1. 65/3 (1971); Verdc.:
528 (1974). Type: Transkei, Umsimkaba River, Drège (B, holo.; GH, K!). Based on Nicolsonia caffra E. Mey.

Nicolsonia caffra E. Mey.: 123 (1836).

Desmodium caffrum (E. Mey.) Druce: 619 (1917); Schindl.: 360 (1927); Bak.f.: 331 (1929); Brenan: 419 (1949); Laundon: 225 (1966), non Eckl. \& Zeyh. (1836), nom. illegit. D. caffrum Eckl. \& Zeyh. is a later homonym of $D$. repandum $(\mathrm{Vahl}) \mathrm{DC}$.

Distribution: $D$. dregeanum is predominantly a low altitude plant from coastal Mozambique to the coast of northern Transkei. It does however occur in the Lydenburg, Barberton and Volksrust Districts of the Transvaal and the hinterland of Natal from $0-1800 \mathrm{~m}$. It is an endemic African species occurring widely in eastern and southern Africa.

Vouchers: Grobbelaar II04 (PRE, PRU); Rogers 28284 (GRA, STE); Ross \& Moll 1830 (NH, PRE); Strey 4971 (NH, NU, PRE); Wood 817 (BOL, SAM).

\section{Note}

The plant is an erect or straggling herb in open grassland most often in moist or marshy areas in sandy soils. It can become a woody subshrub to $1 \mathrm{~m}$ high if protected from fire and it is common in semi-disturbed grasslands, roadsides or forest margins. Flowering may occur throughout the year.

10. Desmodium barbatum (L.) Benth. in Plantae Junghuhnianae 2: 224 (1852); Schubert: 477 (1971); Verdc.: 530 (1974). Type: Jamaica?, Herb Linnaeus 921.48 (LINN, holo.).

\section{Hedysarum barbatum L.: 1170 (1759).}

10a. var. dimorphum (Welw. ex Bak.) Schubert in Bulletin du Jardin botanique de l'Etat, à Bruxelles 22: 298 (1952); Schubert: 205 (1954); Hepper: 564 (1958); Schubert: 478 (1971); Verdc.: 531 (1974). Type: Angola, Cuanza Norte, Golungo Alto, Welwitsch 2165 (LISU, lecto.; K!, BM!); Malawi, Manganya, Kirk (K, syn.!).

Desmodium dimorphum Welw. ex Bak.: 161 (1871); Hutch. \& Dalz.: 417 (1928); Bak.f.: 332 (1929). Nicolsonia barbata (L.) DC. var. dimorpha (Welw. ex Bak.) Schindl.: 359 (1927). D. barbatum (L.) Benth. subsp. dimorphum (Welw. ex Bak.) Laundon: 225, t. 20/A2 (1966).

Distribution: $D$. barbatum var. dimorphum is found in the Transvaal from the Letaba District near Tzaneen south to Lydenburg, Barberton and Nelspruit, from $100-1000 \mathrm{~m}$.

Vouchers: Kluge 1222 (PRE); Krige 139 (J); Liebenberg 2897 (PRE); Scheepers 241 (PRE, PRU); Schrire 66l (NH).

\section{Note}

The plant is a spreading suffrutex to erect subshrub up to $1 \mathrm{~m}$ high, in the grassland component of open woodland, and it flowers from February to June.

10b. var. argyreum (Welw. ex Bak.) Schubert in Bulletin du Jardin botanique de l'Etat, à Bruxelles 22: 298 (1952); Schubert: 205 (1954); Schubert: 479 (1971); Verdc.: 531 (1974). Type: Angola, Huila, Welwitsch 2162 (LISU, holo.; BM!). 
Desmodium dimorphum Welw. ex Bak. var. argyreum Welw. ex Bak.: 161 (1871); Bak.f.: 332 (1929). Nicolsonia barbata (L.) DC. var. argyrae (Welw. ex Bak.) Schindl.: 359 (1927). D. barbatum (L.) Benth. subsp. dimorphum sensu Laundon: 225 (1966), pro parte.

Distribution: $D$. barbatum var. argyreum has been recorded from South West Africa/Namibia.

Voucher: Merxmüller \& Giess 1862 (WIND).

Notes

(1) The plant is erect with silvery-white or fulvous stems which are appressed silky-pilose. The leaves are almost all 1-foliolate with the leaflets densely silverysilky beneath. It occurs in woodland or grassland from $1000-2000 \mathrm{~m}$.

(2) Schubert (1971) notes that, although this variety is quite distinguishable from var. dimorphum in the extreme, there are many plants which form a transition between the two.

Desmodium uncinatum and $D$. intortum or Silverleaf and Greenleaf Desmodium, have been deliberately introduced from central America and cultivated as pasture legumes in the eastern Cape. This is largely out of the natural range of the genus in southern Africa, and there is no evidence that they have become naturalized. Desmodium asperum was once collected on the south coast of Natal but it has not been seen again. A large number of other species of Desmodium are being tested in agricultural stations around the country for their pasture potential.

\section{PSEUDARTHRIA}

Pseudarthria Wight \& Arn., Prodromus florae peninsulae Indiae orientalis 1: 209 (1834); Benth.: 521 (1865); Bak.: 167 (1871); Bak.: 153 (1876); Taub.: 329 (1894); Schindl.: 11 (1914); Hutch. \& Dalz.: 386 (1928); Bak.f.: 338 (1929); Burtt Davy: 381 (1932); Phill.: 419 (1951); J. Léonard: 234 (1954b); Hepper: 585 (1958); White: 161 (1962); Hutch.: 399 (1964); Torre: 231 (1966); Verdc.: 64 (1970); Verdc.: 483 (1971); Verdc.: 534 (1974); Dyer: 264 (1975). Type species: $P$. viscida (L.) Wight \& Arn. (Hedysarum viscidum L.).

Hedysarum L.: 745 (1753), pro parte.

Desmodium Desv. in DC.: 325 (1825), pro parte.

Anarthrosyne E. Mey.: 124 (1836); Harv.: 229 (1862), pro parte; Harv.: 82 (1868).

The name Pseudarthria is derived from the Greek 'pseudo', meaning false, and 'arthron' or joint; the constrictions between the seeds give the impression of the pod being falsely jointed. Only one species occurs in southern Africa.

Pseudarthria hookeri Wight \& Arn., Prodromus florae peninsulae Indiae orientalis 1: 209 (1834); Bak.: 168 (1871); Schindl.: 11 (1914); Hutch. \& Dalz.: 386 (1928); Bak.f.: 339 (1929); Robyns: 313 (1948); Brenan: 436 (1949); J. Léonard: 235, t. 15/A-B (1954b); Hepper: 586 (1958); White: 161 (1962); Torre: 232 (1966); Verdc.: 65 (1970); Verdc.: 484, t. 69/1-9 (1971); Verdc.: 534 (1974). Type: Mauritius, cultivated from Zanzibar, Telfair (K, ?holo.!).
Anarthrosyne robusta E. Mey.: 125 (1836); Harv.: 229 (1862). Type: Transkei, Umgazana, Drège 452 (K!).

\section{var. hookeri}

Verdc. in Kew Bulletin 24: 65 (1970); Verdc.: 484, t. 69/1-9 (1971); Verdc.: 535 (1974).

Distribution: Pseudarthria hookeri var. hookeri occurs in the Transvaal from Louis Trichardt and Tzaneen in the north, between Lydenburg and Skukuza, and between Middelburg and Komatipoort, to Swaziland and Piet Retief in the south. The species also occurs from Pietersburg through Nylstroom to Thabazimbi in the Waterberg Mountains. In Natal the range extends southwards through northern Natal and Zululand to the coast and midlands up to Pietermaritzburg, Richmond, Ixopo and Harding. Further south the range becomes restricted to coastal Transkei to the eastern Cape border. This species occurs widely in tropical and southern Africa, Madagascar, Mauritius and Réunion.

Vouchers: Bos 1300 (PRE, STE); Galpin 776 (GRA, NH, SAM); Hemm 555 (J, PRE, VENDA); Moll 2744 (NH, NU, PRE); Schlechter 4551 (BOL, GRA).

\section{Note}

This species is found most frequently as a suffrutex or subshrub to $3 \mathrm{~m}$ high, in mixed woodland or bushveld, along forest margins, in open grassland or as a ruderal along roadsides or in other disturbed areas, from $0-2000 \mathrm{~m}$. It is also occasionally associated with streambanks, vleis or swampy areas. Flowering occurs between November and May.

\section{ALYSICARPUS}

Alysicarpus Desv., Journal de botanique 1: 120, t.4.f.8. (1813), nom. conserv.; DC.: 352 (1825); Harv.: 230 (1862); Benth.: 522 (1865); Harv.: 82 (1868); Bak.: 169 (1871); Bak.: 157 (1876); Hutch. \& Dalz.: 418 (1928); Bak. f.: 341 (1929); Burtt Davy: 427 (1932); Phill.: 419 (1951); J. Léonard: 84 (1954a); J. Léonard: 223 (1954b); Hepper: 586 (1958); Hutch.: 482 (1964); Torre: 234 (1966); Schreiber: 13 (1970); Verdc.: 491 (1971); Verdc. 544 (1974); Dyer: 264 (1975); Compton: 273 (1976); Dillon: 548 (1980). Type species: A. bupleurifolius (L.) DC. (Hedysarum bupleurifolium L.).

Hedysarum L.: 745 (1753), pro parte.

Fabricia Scop.: 307 (1777); Kuntze: 181 (1891); Taub.: 329 (1894).

Alysicarpus gets its name from the Greek, 'halysis', meaning chain and 'karpos' meaning fruit; the pods are moniliform with the joints in chain formation.

\section{Note}

Alysicarpus Neck.: 15 (1790) is not to be treated as a generic name, according to ICBN Art. 20, unless it has been published, as such, by a subsequent author. Noted in Stafleu (1976) is the following: 'Since Necker designated this category as 'species', the monomial names (which are in many cases the generic names of previous authors) are to be regarded as unitary designations of species and hence to be regarded as not validly published'. 


\section{KEY TO SPECIES}

la Fruit with straight margins, not constricted between the articles; calyx lobes narrow, sharply acuminate, not at all overlapping at the base

1. A. vaginalis

Ib Fruit moniliform, strongly constricted between the articles: calyx lobes ovate-lanceolate, slightly to conspicuously overlapping at the base:

2a Articles smooth; leaves coriaceous with very prominent reticulate venation. 2. A. zeyheri

2b Articles with obvious transverse ridge sculpturing; leaves subcoriaceous with reticulate venation only slightly prorninent:

3a Calyx lobes $0,8-1,5 \mathrm{~mm}$ wide, slightly overlapping and imbricate initially, not so in fruit; inflorescences elongate and spike-like; fruit well exserted from the calyx ......................................4. A. glumaceus

3b Calyx lobes 1,5-2,5 mm wide, conspicuously overlapping and imbricate, and rounded or subcordate at the base; inflorescences often short and compact; fruit only partially exserted from the calyx ............. 3. A. rugosus

\section{SYNOPSIS OF SPECIES}

1. Alysicarpus vaginalis (L.) $D C$., Prodromus systematis naturalis regni vegetabilis 2: 353 (1825); Bak.: 170 (1871), pro parte; Hutch. \& Dalz.: 419 (1928), pro parte; Bak.f.: 342 (1929), pro parte; Robyns: 331 (1948); J. Léonard: 84 (1954a); J. Léonard: 224, t. 13/A (1954b); Hepper: 587 (1958); Torre: 234 (1966); Verdc.: 493, t. 71/A (1971); Verdc.: 546 (1974); Compton: 273 (1976). Syntypes: Ceylon. Hermann (BMHERM, 1:27, 59, syn.).

Hedysarum vaginale L.: 746 (1753).

\section{var. vaginalis}

Verdc. in Kew Bulletin 24: 67 (1970); Verdc.: 493, t. 71/A (1971); Verdc.: 443 (1972); Verdc.: 546 (1974).

Distribution: $A$. vaginalis occurs in the Transvaal Lowveld through Swaziland and Tongaland to the Zululand coast. It is widespread throughout the Old World tropics.

Vouchers: Buitendag 302 (NBG. PRE); Clarke 262 (PRE, PRU); Rogers 25092 (J); Venter 4593 (BLFU. PRE); W'ard 1796 (NH. NU. PRE)

\section{Notes}

(1) The plant occurs as a semi-prostrate or decumbent trailing herb in the herbaceous vegetation of open areas in bushveld or in grassland up to $800 \mathrm{~m}$. More commonly it becomes a weed of disturbed sandy or rocky soils in these areas, i.e. in alluvia, old lands or along roadsides. It flowers nearly all year round from July to May.

(2) A. vaginalis has been introduced into America where it is reported to have no economic importance except as a noxious weed (Schubert 1980). In Africa, however, Schubert (1980) notes that various species including $A$. vaginalis are used locally as, 'fodder, for all kinds of domestic stock, used fresh, but preferably cut after fruiting and stored as hay'. It is also regarded as an excellent fodder for horses, but it is said to cause mucous diarrhoea if given in excess in the young and immature state during the rains. It is also known as Alyce clover, and Allen \& Allen (1981) state that it is considered as a good cover crop in Malaysia to prevent erosion on clay soils of rubber plantations.

2. Alysicarpus zeyheri Harv. in Flora capensis 2: 230 (1862); Bak.: 170 (1871): Hutch. \& Dalz.: 419 (1928); Bak.f.: 343 (1929); Robyns: 332 (1948); J. Léonard: 228, t. 13/C (1954b); Hepper: 587 (1958); Torre:
235 (1966); Verdc.: 494, t. 71/C (1971); Verdc.: 549 (1974). Type: Transvaal, Aapies River, Burke \& Zeyher (K. syn.!; PRE!).

Although quoted as Burke \& Zeyher in Flora capensis, these are two simultaneous but separate collections and are therefore syntypes.

Distribution: $A$. zeyheri occurs in the Transvaal and northern Natal at altitudes between $900-2400 \mathrm{~m}$. It is found from Pietersburg southwards to Pretoria, and from Pretoria westwards to Zeerust in Sourish Mixed Bushveld. East of Pretoria it occurs in the North-eastern Mountain Sourveld and Lowveld Sour Bushveld from Lydenburg, Nelspruit and Barberton down through Swaziland. It also occurs in the North-eastern Sandy Highveld, Piet Retief Sourveld and related veld types from near Middelburg through Ermelo to Louwsburg and Mahlabatini in the south.

Vouchers: Du Plessis 1/36 (PRE. PRU): Galpin 1/58 (GRA. NH. PRE. SAM): Leendertz 399 (BOL. J. PRE): Rudatis 131 (STE): Steyn 995 (NBG).

\section{Notes}

(1) The plant is an erect to spreading herb of open areas in bushveld or in grassland in sandy, rocky or gravel soils, and often occurs in grazed, seasonally burned grassland, along roadsides or railway lines and in old lands. It flowers from October through to April.

(2) Watt \& Breyer-Brandwijk (1962) report that $A$. zeyheri is used as a remedy in South Africa for impotence, while Allen \& Allen (1981) quote a reference in which the species has been used as a snake-bite remedy in some African communities.

3. Alysicarpus rugosus (Willd.) DC., Prodromus systematis naturalis regni vegetabilis 2: 353 (1825); Bak.: 171 (1871), pro parte; J. Léonard: 92, t. 12 (1954a); J. Léonard: 229 (1954b); Hepper: 587 (1958); Lind \& Tallantire: 82 (1962); Torre: 236 (1966); Schreiber: 14 (1970); Verdc.: 495 (1971); Verdc.: 550 (1974); Compton: 273 (1976). Type: Guinea, Isert in Herb. Willdenow (B, holo.).

Hedysarum rugosum Willd.: 1172 (1802).

Alysicarpus violaceus (Forssk.) Schindl.: 13 (1928), pro parte; Hutch. \& Dalz.: 419 (1928), pro parte, non Hedysarum violaceum L. 749 (1753); Forssk.: 136 (1775).

\section{KEY TO SUBSPECIES}

Erect annual; calyx lobes with white cilia; SWANamibia only .......................................... subsp. rugosus

Decumbent spreading perennial with many flexuous stems: calyx lobes with brown to orange cilia ......... subsp. perennirufus 


\section{3a. subsp. rugosus}

J. Léonard in Bulletin du Jardin botanique de l'Etat, à Bruxelles 24: 92, t. 12 (1954a); J. Léonard: 229 (1954b).

Distribution: the typical subspecies is recorded in the Flora area only from the Grootfontein District in South West Africa/Namibia. A specimen, Liebenberg 2789 (PRE), from Barberton in the Transvaal may also be subsp. rugosus, but it is too underdeveloped to be identified with certainty. Subsp. rugosus is an erect annual in open areas in thornveld savanna or in swamps.

Vouchers: Dinter 7628 (BOL. PRE. WIND); Mer.rmüller \& Giess 30098 (WIND).

3b. subsp. perennirufus $J$. Léonard in Bulletin du Jardin botanique de l'Etat, à Bruxelles 24: 95 (1954a); J. Léonard: 230, t. 13/D (1954b); Torre: 236 (1966); Verdc.: 496, t. 71/D (1971); Verdc.: 552 (1974). Type: Congo, Kivu, Rutshuru, Lebrun 902 l (BR, holo.; K!).

Alysicarpus wallichi Wight \& Arn.: 234 (1834); Harv.: 230 (1862). Types: Wallich cat. $5763 a, b$ (K-WALLICH!).

Alysicarpus glaber E. Mey.: 125 (1836). Type: Transkei, between Umzimvubu and Umsikaba Rivers, Drège (K!).

Alysicarpus violaceus (Forssk.) Schindl.: 13 (1928), pro parte; Hutch. \& Dalz.: 419 (1928), pro parte, non Hedysarum violaceum L.: 749 (1753); Forssk.: 136 (1775).

Distribution: this subspecies is widespread in the eastern half of the Flora area, from the Transvaal, Swaziland, Natal to the eastern Cape. In the Transvaal it occurs from Louis Trichardt and Tzaneen in the north through Pietersburg and Potgietersrust to Lydenburg and Komatipoort and to Swaziland in the south. Westwards it occurs from Belfast and Ermelo through Pretoria to Rustenburg with a slight extension into the higher altitude Bankenveld north of Johannesburg and Potchefstroom. The distribution in Natal is chiefly northern Natal from Newcastle to Pongola (an extension of the range in the south-east Transvaal) through the midlands to the coast. It does not occur further west of a line extending from Bergville, Estcourt and Richmond, i.e. into the uplands, nor does it occur further north than Hluhluwe in Zululand. Along the coast and adjacent interior, particularly where there are projections inland of Valley Bushveld, the distribution continues down to East London and inland to the Harding, Umtata. Engcobo and Fort Beaufort Districts.

Vouchers: Acocks 9872 (NH. PRE); Flanagan 416 (GRA. PRE. SAM); Galpin 12975 (BOL, PRE); Moll 1505 (NH. NU, PRE); Tyson 2002 (BOL. NBG. PRE).

Note

Verdcourt (1971) mentions that intermediates occur between the two subspecies in the Flora of tropical east Africa. He notes that a few examples have been found in the Transvaal.

4. Alysicarpus glumaceus (Vahl) DC., Prodromus systematis naturalis regni vegetabilis 2: 353 (1825); Robyns: 332 (1948), pro parte; J. Léonard: 98, t. 13 (1954a); J. Léonard: 231, t. 13/E (1954b); Hepper: 587 (1958); Lind \& Tallantire: 82 (1962); Torre: 236 (1966); Verdc.: 497, t. 71/E (1971); Verdc.: 553 (1974). Type: Yemen, Surdud, Forsskål (C, holo.).

Hedysarum violaceum Forssk.: 136 (1775) non L., nom. illegit. Type as above.

Hedysarum glumaceum Vahl: 106 (1791).
Alysicarpus violaceus (Forssk.) Schindl.: 13 (1928), pro parte: Bak.f.: 342 (1929), pro parte.

\section{subsp. glumaceus var. glumaceus}

Verdc. in Kew Bulletin 24: 68 (1970); Verdc.: 497, t. 71/E (1971); Verdc.: 553 (1974).

Distribution: Alysicarpus glumaceus is found in the hot lowlands of northern Botswana, Transvaal, Swaziland and Natal. In South Africa it occurs from Phalaborwa in the north through Setara and between Louw's Creek and Komatipoort to eastern Swaziland; and in Tongaland and coastal Zululand, south to Eshowe.

Vouchers: Bredenkamp 1847 (PRE); Pooley 726 (NH. NU); Schrire $909(\mathrm{NH})$ : Venter 3765 (ZULU): Ward I89/ (NH. NU).

\section{Notes}

(1) Only the typical taxon is found in the Flora area.

(2) This species occurs as an erect annual herb of open places in bushveld or in grassland, and is often associated with moisture, i.e, floodplains, depressions, saline marshes or near streams. It is also a weed of old lands or along roadsides. Flowering occurs from November to June.

(3) Allen \& Allen (1981) report that this is also known as Alyce clover and, like $A$. vaginalis, is said to be cultivated as a summer graze for domestic animals. Watt \& Breyer-Brandwijk (1962) state that A. glumaceus is used in east Africa as a remedy for thrush and veld sores. In Arabia and India the herb is used as an external application to swollen feet.

\section{Subtribe Lespedezinae}

Lespedezinae (Hutch.) Schubert in Advances in legume systematics 1: 300 (1981).

Lespedezeae Hutch .: 486 (1964).

\section{LESPEDEZA}

Lespedeza Michx., Flora boreali-americana 2: 70 (1803); Hutch.: 487 (1964); Clewel: 365 (1966). Type species: $L$. procumbens Michx.

Hedysarum L.: 745 (1753), pro parte.

The name Lespedeza is derived from Vincento Manuel de Cespedes, governor of the Florida Colony from 1784-1790 and patron of the botanist Michaux. The current spelling of the genus name presumably resulted from illegibility or a printer's error (Allen \& Allen 1981).

Lespedeza cuneata (Du Mont.) G. Don. A general system of gardening and botany 2: 307 (1832); Wilbur: 185 (1963). Type: Japan, Nagasaki, Oldham 328 (K!).

Hedysarum sericeum Thunb.: 287 (1784), nom. illegit.

Anthyllis cuneata Dumont de Courset: 100 (1811).

Lespedeza sericea auct. non Benth.: 227 (1852): (Thunb.) Miq.: 49 (1867).

Distribution: $L$. cuneata is an escape from cultivation, now naturalized in the Natal midlands in the Kokstad. Ixopo and Pietermaritzburg Districts.

Vouchers: Edwards 12 (NH); Hilliard 3888 (NU); Schrire 1368 (NH); Tainion s.n. (NU). 


\section{Notes}

(1) The plant occurs in old lands, along roadsides or old railway lines. It is an herbaceous suffrutex to $0,8 \mathrm{~m}$ high, flowering from February to April.

(2) L. cuneata is native to eastern Asia but is widely cultivated in the United States. Known as Japanese bushclover, it is the most widespread and familiar of all the species and is used extensively to control erosion on roadside banks and similar areas (Wilbur 1963). It is also held in high esteem as a forage, hay and protein supplement to stockfeed (Allen \& Allen 1981).

\section{ACKNOWLEDGEMENTS}

My sincere thanks to the following for much valuable assistance and constructive criticism: Prof. E. Hennessy, Dr B. Schubert, Dr H. P. Linder, Mrs E. Potgieter, Mr G. Nichols, Mr C. Buthelezi and Mr A. Ngwenya.

\section{REFERENCES}

ACOCKS, J. 1975. Veld types of South Africa, 2nd edn. Memoirs of the Botanical Survey of South Africa No. 40:1-128.

ADANSON, M. 1763. Familles des plantes 2: 327-328, 509.

ALLEN, O. N. \& ALLEN, E. K. 1981. The Leguminosae. A sourcebook of characteristics, uses and nodulation. Macmillan, London.

AUBLET, J. B. C. F. 1775. Histoire des plantes de la Guiane française 2: 774. London \& Paris

BAKER, E. G. 1929. The Leguminosae of tropical Africa 2: 324-339. Erasmus Press, Ostend

BAKER, J. G. 1871. Leguminosae. In D. Oliver, Flora of tropical Africa 2: 159-171. Reeve. London.

BAKER, J. G. 1876. Leguminosae. In J. D. Hooker. Flora of British India 2: 142-175. Reeve, London.

BEAUVOIS, A. M. F. J. P. DE 1805. Flore d'Oware et de Bénin en Afrique 1: 326. Paris.

BENTHAM, G. 1852. Leguminosae. In F. A. W. Miquel, Plantae Junghuhnianae 2: 205-269. Leiden.

BENTHAM, G. 1865. In G. Bentham \& J. D. Hooker, Genera plantarum 1, 2: 449-450, 519-522. Reeve, London.

BRENAN, J. P. M. 1949. In J. P. M. Brenan \& P. J. Greenway, Check-lists of the forest trees and shrubs of the British Empire No 5. Tanganyika Territory Part II: 419-436. Imperial Forestry Institute. Oxford

BURTT DAVY, J. 1932. A manual of the flowering plants and ferns of the Transvial with Swaziland. South Africa. Vol. 2. Longmans Green, London.

CLEWELL, A. F. 1966. Native North American species of Lespedeza (Leguminosae). Rhodora 68: 359-405

COMPTON, R. H. 1976. The Flora of Swaziland. Journal of South African Botany Supplementary Vol. No. 11: 272-273.

DE CANDOLLE, A. P. 1825. Prodromus systematis naturalis regni vegetabilis 2: 326-353. Paris.

DESVAUX, N. A. 1813. Journal de botanique, appliqué à l'agriculture, à la pharmacie, à la médecine et aux arts 1: 120-122. Paris.

DILLON, M. O. 1980. Leguminosae for the Flora of Panama. Annals of Missouri Botanical Garden 67: 548-551.

DON, G. 1832. A general system of gardening and botany 2: 307 Rivington, London.

DRUCE, G. C. 1917. Nomenclatural notes: chiefly African and Australian. Reports of the Botanical Society and Exchange Club of the British Isles 1916 4: 619. Oxford.

DUMONT DE COURSET, G. L. M. 1811. Le botaniste cultivateur, edn 2,6: 100. Paris.

DYER, R. A. 1975. The genera of southern African flowering plants. Vol. 1. Department of Agricultural Technical Services, Pretoria.
ECKLON, C. F. \& ZEYHER, K. L. P. 1836. Enumeratio plantarum africae australis extratropicae 2: $251-252$.

FABRICIUS, P. C. 1759. Enumeratio methodica plantarum: 168 Helmstedt.

FORSSKÅL, P. 1775. Flora aegyptiaca-arabica: 136. Copenhagen.

GMELIN, J. F. 1791. In C. Linnaeus, Systema naturae, edn 13, 2 1124. Leipzig.

GUILLEMIN, J. A. \& PERROTTET, G. S. 1832. Florae Senegambiae tentamen 6: 209. Paris.

HARVEY, W. H. 1862. Leguminosae. In W. H. Harvey \& O. W Sonder. Flora capensis 2: 227-230. Hodges, Smith, Dublin.

HARVEY, W. H. 1868. The genera of South African plants, edn 2 Juta, Cape Town

HEPPER, F. N. 1958. Papilionaceae. In J. Hutchinson \& J. M. Dalziel, Flora of West tropical Africa, edn 2, 1: 582-587. Crown Agents for Overseas Governments and Administrations.

HUTCHINSON, J. 1964. Fabaceae. In. The genera of flow'ering plants Vol. 1. Clarendon, London.

HUTCHINSON, J. \& DALZIEL, J. M. 1928. Papilionaceae. In Flora of west tropical Africa, edn 1, Vol. 1. Crown Agents for the Colonies, London.

JACQUIN, N. J. 1776. Hortus botanicus vindobonensis 3: 47, t. 89 Vienna.

KNAAP-VAN MEEUWEN, M. S. 1962. Preliminary revisions of some genera of Malaysian Papilionaceae $\mathrm{V}-\mathrm{a}$ census of the genus Desmodium. Reinwardria 6: 239-276.

KUNTZE, C. E. O. 1891. Revisio generum plantarum. Vol. 1. Leipzig.

LAUNDON, J. R. 1966. Hedysareae. In A. W. Exell \& A. Fernandez, Conspectus florae Angolensis 3: 217-227. Lisbon.

LÉONARD, J. 1954a. Notulae Systematicae XV, PapilionaceaeHedysareae Africanae. Bulletin du Jardin botanique de l'Etat, à Brurelles 24: 84- 102

LÉNARD. J. 1954b. Hedysareae. In, Flore du Congo Belge et du Ruanda-Urundi 5: 223-238. Brussels.

LIND, E. M. \& TALLANTIRE. A. C. 1962. Some common flowering plants of Uganda. Oxford University Press. London.

LINDLEY. J. 1826. A natural system of botany, edn 2. London.

LINNAEUS, C. 1753. Species plantarum. (Facsimile edn 1959) 2: 745-746. London.

LINNAEUS, C. 1759. Systema naturae, edn 10, 2: 1170 . Stockholm.

LUNAN, J. 1814. Hortus Jamaicensis 1: 305. Jamaica.

MEYER. E. H. F. 1836. Commentariorum de plantis Africae australioris 1: 123-124. Leipzig.

MICHAUX, A. 1803. Flora boreali-americana 2: 70. Paris \& Strasbourg.

MILNE-REDHEAD, E. 1937. Tropical African plants: XVII. Bulletin of Miscellaneous Information No. 7: 417. Royal Botanic Gardens, Kew.

MIQUEL, F. A. W. 1867. Annales Musei botanici Lugduno-Batavi 3: 49. Amsterdam.

NECKER, N. J. DE 1790. Elementa botanica 3: 15. Neuwied.

NICHOLSON, D. H. 1978. Illegitimate 'basionyms', impact on priority and author citation, or the rise of Desmodium incanum and fall of $D$. canum (Fabaceae). Taxon 27: 365-370.

OHASHI, H. 197la. A taxonomic study of the tribe Coronilleae (Leguminosae) with a special reference to pollen morphology. Journal of the Faculty of Science, Tokyo University III. 11: 25-92.

OHASHI, H. 197Ib. A monograph of the subgenus Dollinera of the genus Desmodium (Leguminosae). Bulletin. University Museum. University of Tokvo 2: 259-320.

OHASHI, H. 1973. The Asiatic species of Desmodium and its allied genera. Ginkgoana I: 1-318.

OHASHI. H., POLHILL, R. M. \& SCHUBERT. G. B. 1981. Desmodieae. In R. M. Polhill \& P. H. Raven, Advances in legume systematics 1: 292-300. Royal Botanic Gardens, Kew.

PHILLIPS, E. P. 1951. The genera of South African flowering plants, edn 2. Memoirs of the Botanical Survey of South Africa No. 25: $418-419$ 
PLUMIER, C. 1757. In J. Burman, Plantarum americanarum fasciculus primus (-decimus) 6: 140, I. 149, f. I. Leiden.

POIRET, J. L. M. 1805. In J. B. A. P. M. de Lamarck. Encyclopédie méthodique. Botanique 6: 422. Paris.

ROBYNS, W. 1948. Flore des Spermatophytes du Parc National Albert. Brussels.

SCHINDLER. A. K. 1914. Das Genus Pseudarthria Wight \& Arn. Repertorium specierum novarum regni vegetabilis Beihefte 2 : $1-20$.

SCHINDLER, A. K. 1927. Desmodii generumque affinum species et combinationes novae. III. Repertorium specierum novarum regni vegetabilis 23 : $359-360$.

SCHINDLER, A. K. 1928. Die Desmodiinen in der botanischen Literatur nach Linné. Repertorium specierum novarum regni vegetabilis Beihefte 49: 1-371

SCHINZ, H. \& THELLUNG, A. 1913. In G. Schellenberg. H. Schinz \& A. Thellung, Memoires de la Société neuchateloise des science naturelles 5: 371 .

SCHINZ, H. \& THELLUNG, A. 1913. Neues aus: G. Schellenberg, H. Schinz \& A. Thellung, Beiträge zur Kenntnis der Flora von Colombien und Westindien. Repertorium specierum novarum regni vegetabilis 12: 428 .

SCHREIBER, A. 1970. Fabaceae. In H. Merxmüller, Flora von Südwestafrika 60: 13-31. Cramer, Lehre.

SCHRIRE, B. D. 1984. A taxonomic revision of the tribe Desmodieae (Leguminosae-Papilionoideae) M.Sc. Thesis. University of Durban-Westville, South Africa.

SCHUBERT, B. G. 1950. Desmodium: Preliminary studies III. Rhodora 52: $135-155$

SCHUBERT, B. G. 1952. Notes on Desmodium and Droogmansia in the Belgian Congo. Bulletin du Jardin botanique de l'Etat, a Bruxelles 22: 287-307

SCHUBERT, B. G. 1954. Desmodium. Flore du Congo Belge et du Ruanda-Urundi 5: 180-205.

SCHUBERT, B. G. 1963. Desmodium: preliminary studies IV. Journal of the Arnold Arboretum. Hariard University 44: 287-297.

SCHUBERT, B. G. 1971. Desmodium. In E. Milne-Redhead \& R. M. Polhill, Flora of tropical east Africa, Leguminosae-Papilionoideae 1: 451-479. Crown Agents for Overseas Governments and Administrations, London.

SCHUBERT. B. G. 1980. Desmodium. In Flora of Panama. Annals of Missouri Botanical Garden 67: 622-662.

SCHUBERT, B. G. 1981. Desmodieae. In R. M. Polhill \& P. H. Raven, Advances in legume systematics 1: 292-300. Royal Botanic Gardens, Kew.

SCHUBERT. B. G. \& VERDCOURT. B. 1971. Desmodieae. In E. Milne-Redhead \& R. M. Polhill, Flora of tropical east Africa, Leguminoseae-Papilionoideae 1: 450-501. Crown Agents for Overseas Governments and Administrations. London.

SCHULZ-MENZ, G. K. 1964. Coronilleae. In H. Melchior, Engler's Syllabus der Pflanzenfamilien 2: 236-237. Bomtraeger. Berlin.

SCOPOLI, G. A. 1777. Introductio ad historiam naturalem: 307. Prague.

SONDER, O. W. 1850. Beiträge zur Flora von Südafrica. Linnaea 23 32 .

STAFLEU, F. A. (ed.) 1976. Taxonomic literature. Regnum Vegetabile Vol. 52. International Bureau for Plant Taxonomy and Nomenclature. Utrecht.

STAFLEU, F. A. (ed.) 1983. International Code of Botanical Nomenclature. Regnum Vegetabile 111. Junk. The Hague \& Boston.

SWARTZ, O. P. 1788. Nova genera et species plantarum seu prodromus: 106-107. Stockholm. Uppsala \& Abo. Facsimile reprint, Weinheim 1962.

SWARTZ, O. P. 1806. Flora Indiae occidentalis 3: 1263. Erlangen.

TAUBERT, P. 1894. In A. Engler \& K. A. E. Prantl, Die natürlichen Pflanzenfamilien 3, 3: 325-330. Berlin.

THUNBERG, C. P. 1784. Flora Japonica: 287. Facsimile edn 1933, Tokyo.

TORRE, A. R. DA 1966. Hedysareae. In A. W. Exell \& A. Fernandes, Conspectus florae Angolensis 3: 231-237. Lisbon.

VAHL, M. 1791. Symbolae botanicae 2: 82. Copenhagen.
VERDCOURT, B. 1970. Studies in the Leguminosae-Papilionoideae for the Flora of tropical east Africa: 1. Kew Bulletin 24: 64-70.

VERDCOURT. B. 1971. Desmodieae (except Desmodium). In E. Milne-Redhead \& R. M. Polhill, Flora of tropical east Africa Leguminosae-Papilionoideae 1: 483-501. Crown Agents for Overseas Governments and Administrations, London.

VERDCOURT, B. 1972. Studies in the Leguminosae-Papilionoideae-Hedysareae (sensu lato) for the Flora Zambesiaca: 2. Kew Bulletin 27: 443-445.

VERDCOURT, B. 1974. Hedysareae of Flora Zambesiaca. Kirkia 9: $505-554$.

WATT. J. M. \& BREYER-BRANDWIJK. M. G. 1962. The medicinal and poisonous plants of southern and eastern Africa. Livingstone, Edinburgh \& London.

WERGER, M. J. A. 1978. Biogeographical division of southern Africa. In M. J. A. Werger, Biogeography and ecology of southern Africa: 147-170. Junk. The Hague

WIGHT, R. \& ARNOTT, G. A. W. 1834. Prodromus florae peninsulae Indiae orientalis 1: 209-234. Parbury \& Allen, London.

WILBUR, R. L. 1963. The leguminous plants of North Carolina. North Carolina agricultural experiment station technical bulletin 151: 171-195.

WILLDENOW, C. L. 1802. Caroli a Linné Species plantarum editio quarto 3: 1172-1174. Berlin

WHITE. F. 1962. Forest flora of Northern Rhodesia. Oxford University Press. London

WOOD. J. M. 1902. Natal plants 3: 14. Bennett \& Davis, Durban.

\section{SPECIMENS EXAMINED}

Specimens are listed alphabetically according to the name of the collector for each genus. Figures in brackets after the collector's number refer to the number of the taxon in the text.

\section{Desmodium}

Acocks 9648(1) PRE; 10118(1) NH; 10888(2) PRE; 10899(9) PRE; 13332(7) PRE. Ahrens 23(7) NU. Allsopp 969(9) NU; 999(6) NH, NU, PRE; 1017(9) NH; 1024(7) NH, NU.

Baijnath 185(7) NU, PRE. Balsinhas 2804(2) PRE; 3223a(4) PRE. Barker 5155(7) NBG; 6138(2) NBG; 10012(9) NBG. Baur 114(1) BOL, GRA. Bayliss 2757(1) NBG, PRE; 4667(7) NBG. Blenkinson J 14446(1) J. Bokelmann, NBG 67393(1) NBG. Bolus 7731(6) BOL; 8882(9) BOL; 8883(7) BOL; 8884(7) BOL; 11827(7) BOL, PRE; STE 24837(1) STE. Bos 1230(1) PRE, STE; 1253(7) PRE, STE. Bothe 2583(1) PUC. Bourquin 122(7) NU; 253(2) NU; 357(9) NU. Bourquin \& Lawson 1168 (7) NH, PRE; 1171 (9) NH, PRE. Breyer sub TRV 17848(10) PRE; sub TRV 19552(1) PRE. Buitendag 209(6) NBG, PRE; 271(6) PRE, 1155(4) NBG, PRE.

Clarke 269(6) PRU; 371(7) PRE, PRU; 373(1) PRE, PRU; 464(2) PRE, PRU. Codd 1076(1) PRE; 6412(7) PRE; 9312(9) PRE; 9339(7) GRA, PRE; 9362(2) NH, PRE. Codd \& De winter 5144(10) PRE. Codd \& Muller 325(1) PRE. Coleman 13(9) NH, PRE; 65(7) NH, PRE; 1103(3) NH. Collins sub TRV 9895(1) PRE. Comins 1956(9) GRA, PRE. Compton 25075(7) NBG; 25615(1) PRE, SAM; 27287(1) NBG, PRE; 28692(1) NBG, PRE; 30608(7) NBG, PRE. Cooper 204(1) PRE. Crawford 368(2) PRE. Culverwell 1235(4) PRE.

Denley in J 30699(9) J. Devenish 1647(1) NU; $819(1) \mathrm{NH}$, PRE. De Winter \& Killick 8922(1) PRE. Dlamini in NBG 49174 (7) NBG; in NBG 49172(1) NBG; in PRE 55645(1) PRE. Dohse \& Lindahl 94(7) NH, PRE; 98(1) NH, PRE. Dutton 47(9) NH. Dyer 3153(1) PRE. 
Edwards D. 1312(1) NU, PRE; 3250(9) NU, PRE. Eicker s.n.(9) ZULU. Elan-Puttick 16(1) PRE. Eliovson J 26989(1) J. Ellis 2616a(2) PRE. Esterhuysen 12875(1) BOL, PRE. Evans 112(1) $\mathrm{NH} ; 181(9) \mathrm{NH}$.

Fairall 13(6) NBG. Fisher B.S. 590(2) NH, NU; 752(6) NH. Fisher D.K. SAM 66046(1) SAM. Fitzsimons \& Van Dam sub TRV 26257(1) PRE. Flanagan 515(1) BOL, GRA, NBG, NU, PRE, SAM; $2574(9)$ NH, PRE, SAM; 2608(7) PRE, SAM; PRE 55637(1) PRE. Forbes 35(2) NH, PRE; 605(2) NH; STE 13501 (2) STE. Forrester \& Gooyen 187(1) PRE. Fourcade 233(1) BOL, GRA. Frith 121(7) J.

Galpin 1287(1) PRE; 3479(1) BOL; 6303(1) PRE; 9743(2) PRE; 10090(1) PRE; 11005(9) PRE; 11019(2) PRE; 11024 (7) PRE; 11444 (1) PRE; 14457 (1) BOL, PRE; $11858(1) \mathrm{BOL}$, PRE; 11933(1) PRE. Gemmell BLFU 5349(1) BLFU; BLFU 6050(9) BLFU. Gerstner 626(1) PRE; 2936(6) NH; 3845(1) NH; 6005(1) PRE; NH 28779(7) NH. Getliffe 113(2) NU; NU 27810(9) NU. Giffen 837(1) PRE. Gill NH 22592(7) NH. Gillett Mrs. 1203(2) BOL, NH. Gillett J.B. 3156(8) BOL, PRE, STE. Gordon-Gray 94(2) NU; 97(2) NU; 1047(6) NU; 1308 (7) NU. Grobbelaar 59(9) PRU; 66(7) PRE, PRU; 78(7) PRE, PRU; 127 (2) PRE, PRU; 279(9) PRE, PRU; 284(2) PRE, PRU; 649(9) PRE, PRU; 999(9) PRE, PRU; 1104(9) PRE, PRU; 1337(2) PRU; 1807(2) PRU; 1821(9) PRE, PRU; 2312(7) PRU; 2324(7) PRU; 2329(9) PRU. Guy 34(1) NU, PRE.

Hanekom 2299(1) PRE. Harrison 244(9) NH, PRE. Haygarth sub Wood 1061(4) BOL, PRE. Heygarth W. STE 9446(7) STE. Henderson 53(1) BLFU. Hilliard 1095(9) NU; 1134(9) NU; $1227(7) \mathrm{NU} ; 1336(9) \mathrm{NU} ; 1344(7) \mathrm{NU} ; 1365(1) \mathrm{NH}, \mathrm{NU}$; 1951 (1) NU; 2639(7) NU. Hilliard \& Burtt 3310(1) NU; 6852 (4) NU. Hitchins 391(6) PRE. Hofmeyer PRE 55621(1) PRE. Holt 207(10) PRE. Howlett 16(1) NH, NU, PRE; 26(1) PRE; 106(1) NH, PRE. Huntley 195(7) NH, PRE; 686(2) NU. Hutchinson 1759(2) BOL; 2245(8) BOL, PRE.

Jacobs 1757(1) PRE. Jacobsen 2671(1) PRE. Jarman \& Guy 71 (2) NU. Jenkins 7068(7) PRE; sub TRV 7072(9) PRE. Johnson 369(2) NBG; 391(9) NBG. Junod 46(1) PRE; 182(1) PRE; 4357(1) PRE; 4382(7) PRE; 5265(7) PRE; 5267(10) PRE; S270(6) PRE; s $3 b$ TRV 5279(5) PRE; s $4 b$ TRV 5284(10) PRE.

Kalf 35(7) NU; 36(9) NU; 38(2) NU. Keit NH 11142(9) NH. Kemp 1153(1) PRE. Killick 144(1) NU, PRE; 1667(1) PRE. Kuuge 467(1) PRE, PRU; 483(7) PRE, PRU; 1222(10) PRE. Kotze 51(4) WIND. Krige 139(10) J.

Lang sub TRV 32297(6) PRE. L'Ange 86(1) NU. Lawn 3(9) $\mathrm{NH} ; 32(2) \mathrm{NH} ; 72(1) \mathrm{NH} ; 169(7) \mathrm{NH} ; 217(7) \mathrm{NH} ; 752(2)$ $\mathrm{NH}$; $1807(9) \mathrm{NH} ; 2031(9) \mathrm{NH}$. Lawson 307(2) NU; 479(9) NH; 704(9) NH. Leighton 2993(9) BOL; 3083(2) BOL, PRE. Leistner 648(1) PRE. Letty 248(1) PRE; 460(1) PRE. Lewis SAM 61374(1) SAM; SAM 61553(7) SAM; 61554(2) SAM; SAM 68719(1) SAM; SAM 69720(1) SAM. Liebenberg 2374 (10) PRE; 2551(7) PRE; 2897(10) PRE; 2947(1) PRE; 8048 (9) PRE. Louw 2165(7) PUC, STE; 2730(1) PUC, STE.

Macgregor 64(9) NU. Martin A.J. $061(8)$ NU. Martin B. 191(2) NBG. Mauve 4099(9) PRE. McClean 183(7) PRE; 439(9) NH; 496(9) NH. McDonald 118(6) E, K, NU, PRE. Medley Wood 93 (9) BOL, SAM; NH 163(9) NH; 209(9) BOL, SAM; 508(1) BOL, SAM; 644(2) BOL, SAM: 790(7) BOL; $817(9) \mathrm{BOL}$, SAM: 3010(4) NH, SAM; 3103(1) NH; 3129(9) NH; 3134(2) NH; 4936(6) BOL, PRE, SAM; 4936(6) GRA; 5350(1) PRE; 5591(9) PRE; NH 6416(7) NH; 9788(7) NBG; 11845(9) PRE. Merxmüller \& Giess 1862(10) WIND. Miller PRE 55638(2) PRE. Miller O.B. 4279(1) PRE. Mogg 4399(7) PRE; 4891(7) PRE; 11921(9) PRE; 12700(9) PRE; 13072(9) PRE; 13455(9) PRE; 33984(1) J; J 36211(1) J. Mohle 268(1) PRE. Moll 2471(6)
PRE; 2720(8) NU, PRE; 3439(1) NU, NH; 4767(9) NH, PRE; $5406(7) \mathrm{NH} ; 5410(2) \mathrm{NH} ; 5421(1) \mathrm{NH}$. Moll \& Nel 5610(4) NH, PRE. Moll \& Strey 3896(8) NH, PRE. Morgan 70(1) PRE. Morris 175(6) NU; 190(2) NU; 195(9) NU. Moss 3298(7) J 3298(2) J, PRE; J 3299(9) J; 3300(1) PRE; J 14213(1) J; $J$ 15784(1) J; J 18018(1) J. Mtombeni 26(2) ZULU; 40(7) ZULU. Muller 2352(1) PRE. Muller \& Giess 544(4) PRE, WIND.

Netshiungani (7) VENDA. Nichols 423(8) NH; 433(3) NH; 477(1) NH. Nicholson 105(9) NH; 1200(7) PRE.

Oatley 26(9) PRE. Obermeyer sub TRV 29363(6) PRE; sub TRV 30325(1) PRE; sub TRV 30371(1) PRE. Otto 124(7) PRE.

Parkhouse NBG 16886(9) NBG. Phillips E.P. PRE 55667(7) PRE. Phillips J. J 35347(1) J. Pole-Evans 970(1) PRE; 4549(1) PRE. Pott 5334(6) PRE; 5335(1) PRE. Prosser 1840(1) PRE.

Randles 10(1) NU. Rehmann 8699(7) BOL. Repton 5862(1) PRE. Rogers 1259(9) PRE; 11606(9) J; 15059(9) J; 15060 (2) SAM; $15061(2) \mathrm{J} ; 18410$ (9) PRE; s $4 b$ TRV 20707(6) PRE; $23564(6) \mathrm{NH} ; 26050(10)$ PRE; 28284(9) GRA, STE. Ross 78 (2) $\mathrm{NU} ; 208(7) \mathrm{NU} ; 723(7) \mathrm{BLFU}, \mathrm{NH}, \mathrm{NU} ; 775(7) \mathrm{NU} ; 1679$ (7) NH, NU, PRE; $1822(9) \mathrm{NH}, \mathrm{PRE} ; 1994(1) \mathrm{NH}, \mathrm{PRE} ; N U$ $25765(7) \mathrm{NU}$; NU 25769(1) NU. Ross \& Moll 1830(9) NH, PRE; 1841 (8) NH, PRE; $2267(2)$ NH, PRE. Rudatis 68(9) STE; 115(1) STE; 288(9) PRE; 334(1) PRE; STE 2339(7) STE. Rump NH 21063(9) NH; 147-1929(9) NY; Feb. 1931(9) NU. Rycroft 2420(4) NBG; 2601(2) NBG.

Sanderson 870(1) NH. S.A.R. PRE 55639(2) PRE. Scheepers 24l(10) PRE, PRU; 248(1) PRE, PRU; 581(7) PRE, PRU; Scheepers \& Haasbroek Alkaloid survey SKF no. 1140(7) PRE. Schelpe 51(9) BOL. Schlechter 3129(6) BOL, GRA, PRE; 3354 (7) PRE; 4742(1) PRE; 6668(7) BOL; 12105(8) SAM; 12275 (10) BOL, SAM. Schonken 15(1) STE. Schonland 845(1) GRA, PRE. Schrire 153(6) NH; 262(2) NH; 263(2) NH; 264(2) NH; $265(2) \mathrm{NH} ; 266(2) \mathrm{NH} ; 267(7) \mathrm{NH} ; 268(8) \mathrm{NH} ; 272(2) \mathrm{NH}$; $273(7) \mathrm{NH} ; 274(7) \mathrm{NH} ; 275(2) \mathrm{NH} ; 276(2) \mathrm{NH} ; 277(9) \mathrm{NH}$; $278(2) \mathrm{NH} ; 283(7) \mathrm{NH} ; 284(9) \mathrm{NH} ; 285(9) \mathrm{NH} ; 286(9) \mathrm{NH}$; $287(9) \mathrm{NH} ; 288(2) \mathrm{NH} ; 289(9) \mathrm{NH} ; 290(8) \mathrm{NH} ; 291(2) \mathrm{NH}$; 292(8) NH; 293(2) NH; 294(9) NH; 296(9) NH; 297(8) NH; $332(2) \mathrm{NH} ; 335(1) \mathrm{NH} ; 340(2) \mathrm{NH} ; 350(2) \mathrm{NH} ; 356(9) \mathrm{NH}$; 382(9) NH; 385(4) NH; 386(8) NH; 392(2) NH: 396(7) NH; $399(1) \mathrm{NH} ; 655(5) \mathrm{NH} ; 661(10) \mathrm{NH} ; 671(2) \mathrm{NH} ; 716(9) \mathrm{NH}$; $717(2) \mathrm{NH} ; 855(9) \mathrm{NH} ; 881(9) \mathrm{NH} ; 882(7) \mathrm{NH} ; 883(6) \mathrm{NH}$. Shuter 59(9) NU. Sidey 3876(2) PRE; 3976(9) NH, PRE; 4186 (9) PRE. Sim 4057(1) GRA, PRE. Smith 693(4) PRE; 2331(4) PRE. Stanton 70(1) NU. Stephen, Van Graan \& Schwabe 1197 (9) PRE. Stirton 39(1) NU; 462(9) PRE; 508(2) PRE; 536(9) PRE; $1753 a$ (1) PRE; $1753 b$ (1) PRE; 5362(2) PRE; 8685(10) NH. Strey 2996(7) NH, PRE; 3725(1) PRE; 3873(9) NH, PRE; 4103(1) PRE; 4559(2) NH, PRE; 4887(9) NH, PRE; 4971(9) NH, NU, PRE; 5486(7) NH, PRE; 6354(2) NH, PRE; 7151(8) NH, NU. PRE; 7394(2) NH, PRE; 7843(1) NH; 8530(1) NH, PRE; $9618(7) \mathrm{NH}, \mathrm{NU}, \mathrm{PRE}$; $10752(1) \mathrm{NH}, \mathrm{NU}, \mathrm{PRE} ; 10937$ (7) NH, PRE. Swierstra PRE 55605(1) PRE.

Taylor R.H. 85(9) NU. Theron 1600(1) PRE; 3612(1) PRE, PRU. Thode A317(1) NH, PRE; STE 3802(9) STE; STE 3803 (7) STE; STE 3805(9) STE; STE 6443(1) STE. Thomcroft 893 (7) NH; Gov. Herb. 11361 (7) PRE. Thorpe NH 29880(1) NH. Tinley 343(8) PRE; $1487(4)$ WIND. Tomlinson 2/115(9) NH. Trauseld 375(1) PRE. Tyson 1165(1) BOL; 1438(7) SAM, STE; 1439(1) SAM, STE; 1525(1) PRE, SAM; 2144(1) BOL; 2782(7) PRE, SAM; 2816(1) SAM; 3151(1) PRE.

Vahrmeijer 541(8) PRE; $667(4)$ NH, PRE. Vahrmeijer \& Hardy 1627(9) PRE. Vahrmeijer \& Tölken 859(4) PRE; 8282(9) PRE. Van der Merwe D.D. PRE 58466(6) PRE. Van der Merwe P. 312(1) PRE. Van der Schijff 965(6) PRE, PUC; 1132(6) PRE; 1325(6) PRE; 2023(9) PRE; 2419(10) PRE; 2659(5) PRE; 
4332(1) PRE, PRU; 4941(1) PRE, PRU; 5066(7) PRE, PRU; 5976(7) PRE, PRU; 6437(7) PRE, PRU. Van Jaarsveld 12(4) NBG; 678(4) NBG, PRE; 3800(1) NBG. Van Son sub TRV 30688(1) PRE. Van Vuuren 88(1) PRE. Van Wyk 915(1) PRE, PUC. Venter F. 697(1) PRE. Venter H.J.T. 7(2) ZULU; 300 (2) BLFU; $570(9) \mathrm{NH;} \mathrm{634(9)} \mathrm{NH;} \mathrm{729(9)} \mathrm{ZULU;} \mathrm{832(7)}$ ZULU; 2273(2) ZULU; 2289(7) BLFU; 2424(1) PRE, ZULU; 3303(9) ZULU; 3304(7) ZULU; 3485(1) ZULU; 4547(9) BLFU; 4993(4) PRE, ZULU; 4996(7) ZULU; 5283(8) BLFU; 5291(8) PRE, ZULU; 5489(4) PRE, ZULU. Verdoorn PRE 58467 (1) PRE. Vogt PRE 55600(1) PRE. Vorster L.L. 15(1) PRU. Vorster P. 2623(8) PRE.

Wager H.A. sub TRV 22462(6) PRE; sub TRV 22988(1) PRE; sub TRV 24101(2) PRE; PRE 55633(1) PRE. Wager V. C45(7) PRE. Ward 222(9) NU; 584(2) NU, PRE; 733(7) NU, PRE; $1874(9) \mathrm{NH}, \mathrm{NU} ; 1875(9) \mathrm{NH}, \mathrm{PRE} ; 2155(1) \mathrm{NU} ; 2406(6)$ NH, PRE; 4361(9) NH, PRE; 5381(7) NH, PRE; 5389(9) NH, $\mathrm{NU}, \mathrm{PRE} ; 5498(1) \mathrm{NU} ; 5560(4) \mathrm{NH}, \mathrm{NU} ; 6263(2) \mathrm{NU} ; 6375$ (9) NH, NU, PRE; 6509(9) NH, NU; 7601(7) NU; 7696(9) $\mathrm{NH}$, NU. Watmough 486(2) PRE. Weeks 82(9) J. Wells 1429 (2) NU; 2880(1) GRA, NH, PRE; 3375(2) GRA, PRE; 4263 (2) $\mathrm{NH}$; 4266(2) PRE. West 1089(1) PRE. Williams 8(7) NU. Williams Miss sub TRV 7622(1) PRE. Wilson 35(9) NU. Wylie sub Wood 8990(4) NH; 10335(4) GRA, PRE, SAM, STE.

Young PRE 55596(1) PRE; PRE 55607(1) PRE.

\section{Pseudarthria hookeri}

Acocks 1217 PRE; 232136 PRE. Adlam SAM 15562 SAM. Ahrens 13 NBG. Allsop 800 NU.

Barrett 532 PRE. Baylis 1145 PRE. Biggs 197 PRE. Bolus 8885 BOL; 10949 BOL, PRE. Bos 1300 PRE, STE. Botha 1335 PRE, PUC. Boulle 8 NU. Bourquin 127 NU. Breyer sub TRV 17844 PRE; sub TRV 18387 PRE; PRE 55685 PRE. Britten 4753 GRA, PRE. Brown \& Shapiro 464 PRE. Buitendag 498 NBG, PRE. Burtt Davy 1451 PRE; 1546a PRE; 2923 PRE.

Cholmondely PRE 55672 PRE. Clarke 47 PRE, PRU. Codd 5918 PRE; 6015 PRE. Codd \& Muller 329 PRE. Coetzer 211 BLFU, PRU. Coleman $66 \mathrm{NH}$. Collins sub TRV 9892 PRE. Comins $88 \mathrm{NH}, \mathrm{NU}$; 1948 GRA, PRE. Compton $24876 \mathrm{NBG}$; 26606 NBG, PRE; 27393 NBG, PRE; 31263 NBG, PRE. Crawford 434 PRE. Cross 86 NBG.

Davison 91 PRE. Devenish 629 PRE. Dimock Brown 356 PRE; 482 PRE. Dohse \& Lindahl 104 NH, PRE. Dyer 3152 PRE.

Eliovsen J 27186 J. Edwards 6 NU. Elan-Puttick 255 PRE.

Flanagan 2534 PRE, SAM; 2571 PRE. Frith 141 J.

Galpin 776 GRA, NH, SAM; 778 PRE; 13727 PRE; 14386 PRE; BOL 32274 BOL; BOL 32275 BOL. Gerstner 6216 BOL. Gordon-Gray 1372 NU. Grobbelaar 448 PRE, PRU; 2310 PRU.

Harding sub TRV 5181 PRE. Harrison 450 NH, PRE. Haygarth STE 214 STE. Hemm s.n. VENDA, J. PRE. Hilliard $1325 \mathrm{NH}$, NU. Hitchins 737 NH, PRE. Holt 42 PRE; $42 \mathrm{NH}$; $192 \mathrm{NH}$, PRE; 207 NH. Huntley 209 NH, NU, PRE. Hutton 50 GRA.

Indian collector NH $17731 \mathrm{NH}$; sub TRV 34012 PRE.

Jacobsen 2255 PRE. Jenkins sub TRV 7077 PRE; PRE 55702 PRE; PRE 55703 PRE. Johnson 368 NBG. Junod 2369 PRE; 4381 PRE.

Killick 74 PRE. Kluge 410 PRE, PRU; 1183 PRE.
Lawn 305 NH. Leach 12109 PRE. Letty 441 PRE. Liebenberg 2379 PRE. Louw 2134 PUC, STE. Lovell PRE 55698 PRE.

Macgregor 55 NU. Maguire 689 J. Mc Callum PRE 55668 PRE. McClean 129 PRE; 147 PRE. Medley Wood 802 SAM, BOL, PRE; 1036 BOL, SAM; NH 1491 NH; 7402 PRE; 9992 NH. Meeuse 9884 PRE. Moll 1527 NH, NU, PRE; 2744 NH, NU, PRE; 5265 NH, PRE. Morgan 67 PRE. Morris 786 NH, NU, PRE. Moss 18448 J. Mudd PRE 55678 PRE. Muller 2475 PRE. Murray 690 PRE.

Nicholson $236 \mathrm{NH}$.

Obermeyer 319 PRE; 484 PRE.

Pegler 697 BOL, PRE. Pierce 6 PRE. Pole-Evans H. 17030 PRE. Pooley \& Joubert 2013 E, K, NU, MO.

Rehmann 6281 BOL. Repton 3482 PRE. Robbertse 102 PRU. Rogers STE 13602 STE; 24054 PRE. Ross $85 \mathrm{NU} ; 271 \mathrm{NU}$; 771 BLFU; 780 NU. Rudatis 392 STE. Rump NH 10403 NH.

Scheepers 106 PRE, PRU; 320 PRE, PRU. Schlechter 4551 BOL, GRA; s b TRV 2220 PRE; sub TRV 13151 PRE. Schlieben 9478 PRE; 10183 PRE. Schrire $295 \mathrm{NH} ; 397 \mathrm{NH} ; 400 \mathrm{NH}$; $484 \mathrm{NH} ; 663 \mathrm{NH} ; 857 \mathrm{NH} ; 859 \mathrm{NH} ; 872 \mathrm{NH}$. Smith PRE 55688 PRE. Smuts 255 PRE; 301 PRE. Stephan 298 PRE; 581 PRE. Stition $1751 b$ PRE. Strey 3322 PRE; $4686 \mathrm{NH}$, PRE; 9721 NH, PRE.

Theron 2351 PUC. Thode STE 3456 STE; STE 6367 STE. Thorncroft 402 PRE; sub TRV 2849 PRE. Tyson 1440 PRE, SAM, STE; 2046 SAM.

Venter 744 ZULU; 870 BLFU; 2300 ZULU; 5212 PRU, ZULU. Verdoom 2442 PRE. Vahrmeijer 2403 PRE. Van Dam PRE 55684 PRE. Van der Merwe 106 PRE. Van der Schijff 722 PRE; 4577 PRE, PRU. Van Elden 1 PRE. Van Rooyen 6 NU. Van Son sub TRV 30436 PRE. Van Wyk A.E. 2568 PRU; 4044 PRE.

Wade NU 52896 NU. Wager C. 30 PRE. Ward 2069 NU, PRE; $2510 \mathrm{NH}, \mathrm{PRE} ; 7591$ PRE. Watson $3 \mathrm{PRE}$. Wells $1111 \mathrm{NU}$, PRE; $4270 \mathrm{NH}$; NU $34142 \mathrm{NU}$. Werdermann \& Oberdieck 2116 PRE. Williamson 269 PRE. Wilson 20 NU. Wood 156 NU.

\section{Alysicarpus}

Acocks 9872(3) NH, PRE; 13160 (2) PRE.

Barker 2742(3) BOL, NBG; 4282(3) NBG. Barrett 348(4) PRE. Baur 572(3) SAM. Bolus 11074(2) BOL; 11829(2) BOL, PRE. Bourquin 103(3) NU; 371(1) NU; 650(1) PRE. Bredenkamp 1737(4) PRE; 1739(4) PRE; 1847(4) PRE; 1865(1) PRE. Bredenkamp \& Van Vuuren 139(2) PRE; 293(3) PRE. Breyer sub TRV 17056(1) PRE; sub TRV 17857(1) PRE; sub TRV 20903(3) PRE; PRE 55731(2) PRE; PRE 55733(2) PRE. Buitendag 302(1) NBG, PRE. Burke PRE 9323(2) PRE. Burtt Davy 804(2) PRE; 811(3) PRE. Buthelezi 114(3) NH; 142(3) $\mathrm{NH} ; 150(2) \mathrm{NH} ; 168(3) \mathrm{NH} ; 218(3) \mathrm{NH} ; 252(3) \mathrm{NH}$.

Clarke 131(2) PRU; 262(1) PRE, PRU; 263(3) PRE, PRU; 470 (3) PRE, PRU; 523(1) PRU. Codd \& De Winter 4884(1) PRE; 4964(1) PRE. Coetzee B.J. 6063(4) PRE. Coetzee NH 35014 (3) NH. Coetzer 103(2) PRE; 135(1) PRE. Compton 28332(3) PRE; 28348(1) NBG, PRE. Comins 436(3) NU; 1779(3) GRA, PRE. Culverwell 1183(2) PRE; 1196(3) PRE; 1325(1) PRE. Cuthbert NU 52685(3) NU. 
Devenish 929(3) PRE. De Winter 7692(3) PRE. Dinter 7628(3) BOL, PRE, WIND. Dixon 21(3) NU. Du Plessis 1136(2) PRE, PRU.

Elan-Puttick 246(2) PRE. Ellis 2616b(3) PRE.

Fisher 743(3) NH, NU. Flanagan 416(3) GRA, PRE, SAM; $2802(3) \mathrm{NH}$, PRE. Forbes 738(3) NH. Frankish 66(3) NU.

Galpin 1158(2) GRA, NH, PRE, SAM; 3408(3) BOL, PRE; 5779(3) PRE; 9729(3) PRE; 12975(3) BOL, PRE. Germishuizen 388(2) PRE; 551(2) PRE; 654(2) PRE. Gerstner 4209(3) NH; 6844(4) PRE; NH 33781(2) NH. Gertenbach 7021(4) PRE. Giffen 1070(3) PRE; 1096(3) PRE. Gordon-Gray 1128 (3) NU. Gordon Truscott 7a(3) PRE. Grobbelaar 2(3) PRE, PRU; 5(3) PRU; 323(3) PRE, PRU; 2320(3) PRU.

Hall \& Sons PRE 55715(1) PRE. Hanekom 1913(3) PRE. Hilliard 1259(3) NU; $1848(3)$ NU; 1943(3) NU. Hitchins $866(3)$ PRE. Huntley 1502(2) PRE. Hutton 1031(3) GRA, NBG.

Jacobsen 1588(3) PRE. Jacobsz 768(3) PRE; 805(3) PRE.

King 57(3) PRE; 64(3) PRE.

Lawn 1120(3) NH; 1908(3) NH. Leeman 23(3) PRE. Leendertz 399(2) BOL, J, PRE; 407(3) PRE, SAM; s PRE; sub TRV 8754(2) PRE; sub TRV 11298(2) PRE. Lennox NU 28057(3) NU. Liebenberg 2788(2) PRE; 3293(1) PRE; 3298(3) PRE; 5308(3) NH; 5312(2) NH; 8482(2) PRE; 8721 (3) PRE.

Mauve 5298(3) NH. Medley Wood 274(3) NH; 6091(3) BOL. Merxmuller \& Giess 1862(3) WIND; 30098(3) WIND. Mogg 5960(3) NH, PRE; 6143(3) PRE; 6603(3) PRE; 15064(3) PRE. Moll 1057(3) NU, PRE; 1505(3) NH, NU, PRE; $1686(3)$ NU, PRE; 2595(3) NU, PRE. Moss 383(3) J; 8490(2) J; 13214 (2) J. Moss \& Rogers 517(1) J; 602(1) J; 993(3) J.

Obermeyer 148(3) PRE; 1144(3) PRE. Obermeyer \& Van Nouhuys sub TRV 27805(3) PRE.

Pegler 163(3) PRE; 1459(3) PRE. Pelletier J 30510(3) J. Penny Col. Herb. 2388(3) PRE. Pooley 726(4) E, K, NH, NU. Pott 5073(3) PRE; s $b$ b TRV 15081(3) PRE; 5345(2) PRE. Preller 139(3) PRE. Purce PRE 55727(1) PRE.
Ranger 302(3) PRE. Rattray 616(3) GRA. Reachmoor PRE 11854(1) PRE. Rehmann 461(3) BOL. Repton 87(3) PRE; 838(3) PRE; 2767(2) PRE; 2785(3) PRE. Rogers 301(3) GRA; sub TRV 5165(3) PRE; 10931(3) PRE; 14394(3) J, PRE; 18294(3) J; 21921(2) PRE; 24860(3) PRE; 25092(1) J. Rudatis 131(2) STE; 1365(3) STE; 1729(3) PRE. Rump NH 20290(3) NH; NH 20328(3) NH.

Scheepers 176(3) PRE, PRU. Schlechter 3121(3) PRE; 3221(3) BOL, PRE. Schrire 269(3) NH; 270(3) NH; 271(3) NH; 403(3) $\mathrm{NH} ; 667(3) \mathrm{NH} ; 874(3) \mathrm{NH} ; 909(4) \mathrm{NH} ; 1120(2) \mathrm{NH} ; 1320$ (3) NH. Shirley 304(3) NU; NU 32878(3) NU. Sim 19436(3) PRE; 20175(3) PRE, NU. Smith 1451(3) PRE; 2443(4) PRE Smuts \& Gillett 2214(3) PRE. Steyn 995(2) NBG. Stirton 5076 (3) PRE; 5190(3) PRE; 5757(3) PRE; 10516(3) NH. Strey 4808(3) NH; $9115(2) \mathrm{NH}$, PRE.

Taylor 55(4) NH. Theiler PRE 55709(3) PRE. Thode STE 6662 (3) STE. Tinley 751(3) NU. Tyson 23(3) GRA, NH, PRE; 1441 (3) SAM, STE; 1196(3) PRE, SAM; 2002(3) BOL, NBG, PRE.

Vahmeijer \& Tölken 905(1) NH, PRE. Van Dam 21137(4) PRE. Van der Schijff 437(1) PRE; 1396(1) PRE; 5290(3) PRE, PRU; 5291(2) PRE, PRU; 5291(3) PRE. Van Rensburg 2(3) NU. Van Vuuren 531(2) NH. Van Wyk 4712(1) PRE. Venter 774(1) ZULU; 1699(3) NH, PRE; 1969(3) ZULU; 3436(3) ZULU; 3765(4) ZULU; 4593(1) BLFU, PRE. Verdoom 135(3) PRE.

Wahl sub TRV 15525(3) PRE; PRE 55723(3) PRE. Ward 1512 (3) NH, PRE; 1796(1) NH, NU, PRE; 1891 (3) NH, NU; 2426 (1) NH, NU, PRE; 8805(1) PRE. Wilms 5873(3) PRE. Wylie NH 28026(3) NH.

Young A331(3) PRE.

Zeyher SAM 32864(2) SAM.

$S A G P / S A A B$ 1/113(3) PRE, PRU.

\section{Lespedeza cuneata}

Edwards 12 NH.

Hilliard 3888 NH, PRE.

Schrire $1368 \mathrm{NH}$.

Tainton sn. NU. 